\title{
CURRENT ISSUES IN THE ECONOMICS OF GROUNDWATER RESOURCE MANAGEMENT
}

\author{
Phoebe Koundouri* \\ University of Reading and University College London
}

\begin{abstract}
The issue of groundwater management remains a practical concern in many regions throughout the world, while water managers continue to grapple with the question of how to manage this resource. In this article, we attempt to bring the most advanced and appropriate tools to bear on the issue of resource allocation involving groundwater. Our objective is to demonstrate the state of the art in the literature on ways to think about this complex resource and to deal with the important economic issues emanating from its complexity. We present the conceptual framework within which economists examine the elements interacting in the management of groundwater resources, indicate why the role of the market is limited with respect to the price of this very complex resource, and point to the mechanisms that can pull competitive groundwater price and quality-graded quantity of groundwater in line with their equilibrium levels. In particular, we critically review economic models of groundwater use, examine the potential for groundwater management, discuss the difficulties encountered in the estimation of the relevant control variables of such models, and identify the advantages and limitations of the instruments devised for the efficient use (allocation) of this resource. Finally, we argue that devised regulatory schemes usually ignore the information and knowledge needed for their implementation, and we suggest a core of conditions necessary for successful groundwater management reforms.
\end{abstract}

Keywords. Groundwater Management; Economic Instruments; Political Economy of Reform

\section{Introduction}

The issue of groundwater management remains a practical concern in many regions throughout the world, while water managers continue to grapple with the question of how to manage this resource. Groundwater constitutes about $89 \%$ of the freshwater on our planet (discounting that in the polar ice caps);

\footnotetext{
*The author is a lecturer in economics at the University of Reading and a senior research fellow at University College London.
} 
hence, given the well-documented world water scarcity, it is one of the most important natural resources that we are challenged to manage. Groundwater systems are dynamic with groundwater continuously in slow motion from zones of recharge to areas of discharge. Tens, hundreds or even thousands of years may elapse in the passage of water through this subterranean part of the hydrological cycle, since flow rates do not normally exceed a few meters per day and can be as low as $1 \mathrm{~m}$ per year. ${ }^{1}$ Groundwater is primarily a depletable resource stock, although at a small proportion $(<5 \%)$ it can be withdrawn each year and renewed by seepage of rainwater or snow melting into the aquifer. The extensive use of groundwater in many parts of the world and related environmental harm (i.e. water-level drawdown, aquifer mining and pollution, saltwater intrusion, stream baseflow reduction, and land-surface subsidence) implies the difficulty of efficiently and equitably defining, allocating, and protecting rights to a common, fluid resource through market mechanisms.

Many economists have relatively recently discovered that the problem of groundwater resource management is an important and interesting area for the application of the tools of economic theory and econometrics. At the same time, many water specialists from other disciplines have discovered that the language and tools of economics are helpful in furthering the understanding of water management problems. For these reasons, this branch of economics has developed rapidly in recent decades and is likely to continue to do so. Although there exist a few literature reviews on the economics of conjunctive use of surface and groundwater (Provencher, 1995; Zilberman and Lipper, 1999; Becker et al., 2001; Tietenberg, 2002), this article is, to the best of our knowledge, the first comprehensive attempt to review the vast amount of economic issues relevant to groundwater resources.

In this article, we present the conceptual framework within which economists examine the elements interacting in the management of groundwater resources, indicate why the role of the market is limited with respect to the price of this very complex resource, and point to the mechanisms that can pull competitive water price and quality-graded quantity of groundwater in line with their equilibrium levels. In Section 2, we review the existing economic models of groundwater use and examine the potential of groundwater management for each of these models, while in Section 3, we discuss the techniques that can be used and the difficulties encountered in the estimation of the relevant control variables of such models. In Section 4, we examine the advantages and limitations of instruments devised for the efficient use (allocation) of this resource, both in quantity and in quality terms. In Section 5, we argue that devised regulatory schemes for groundwater management usually ignore the information and knowledge needed for their implementation. The schemes also underestimate distortions arising from misspecification of relationships among individuals and organizations. Therefore, in most cases, economists actually produce second-best solutions. As a result, evaluating the consequences of these pricing or other reforms can be difficult. The political economy literature surveyed in Section 5 suggests a core of conditions necessary for successful groundwater management reforms.

(C) Blackwell Publishing Ltd. 2004 


\section{Models of Groundwater Use and the Potential for Groundwater Management}

Implicit in the concern about groundwater is the belief - prominent among resource economists - that in the absence of intervention, groundwater is misallocated. This section discusses the inefficiency of groundwater pumping in the absence of central (optimal) control and emphasizes that the estimates of the welfare loss under the common property regime depend on the particular model of firm behavior enlisted in the analysis. This allows us to conclude in favor of an existing potential and pressing need for the development and implementation of management policies for groundwater resources.

When groundwater withdrawals exceed recharge, the resource will be mined over time until either supplies are exhausted or the marginal cost of pumping additional water becomes prohibitive. The first implication of this is that a marginal user cost is associated with mining groundwater, reflecting the opportunity cost associated with the unavailability in the future of any unit of water used in the present. An efficient allocation considers this user cost, which effectively signals the in situ scarcity of the resource and is called the resource's scarcity rents. Hence, efficient pricing of a resource that exhibits natural supply constraints incorporates both marginal cost of extraction and scarcity rents. Scarcity rents must be imposed on current users.

Figure 1 graphs this argument. The dotted line depicts marginal extraction costs for existing, conventional water sources, such as irrigation wells. If these sources were not available, the alternative would be a backstop source such as desalination, which we assume to be available in unlimited quantities though at a high (and constant) cost $(\bar{p})$. Suppose that, contrary to the common situation, all rights to in situ groundwater could be owned and sold independently of the overlying land. The shadow price of groundwater would be bounded at the high

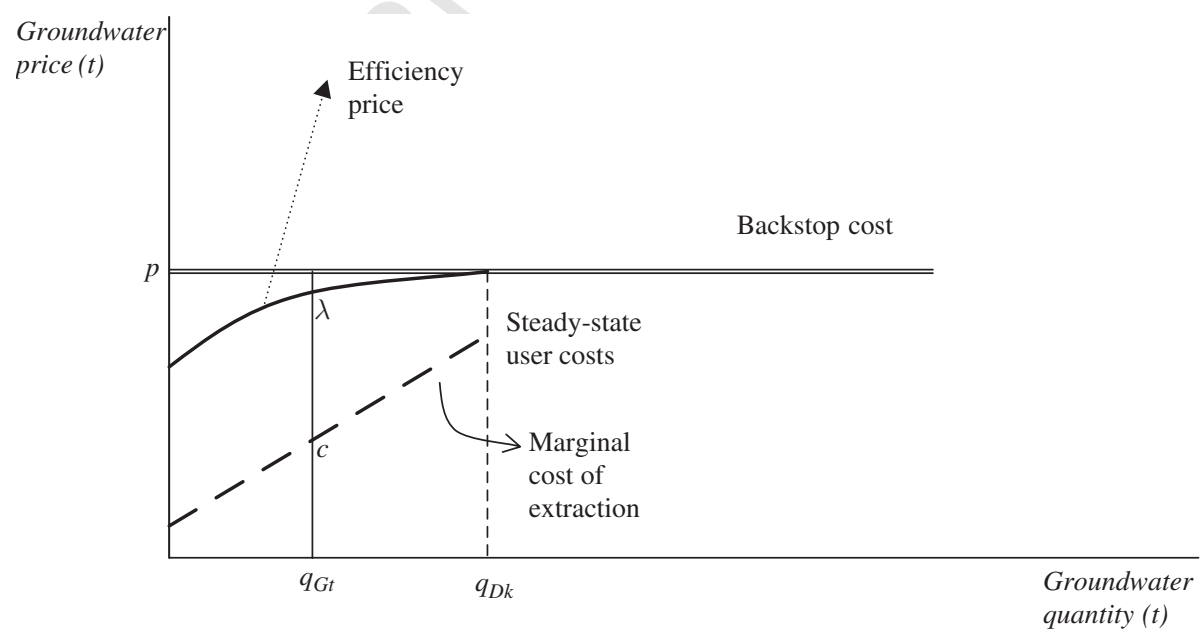

Figure 1. Extraction cost, scarcity rents, and efficiency price of groundwater. 
end by what prospective buyers are willing to pay $^{2}$ and at the low end by what sellers are willing to accept. ${ }^{3}$ At (marginal) capacity $\left(q_{\mathrm{Gt}}\right)$, potential scarcity rent is the distance $(c \lambda)$. The efficiency price line shows the efficient price for water, incorporating extraction costs as well as scarcity rents.

Given the difficulty of establishing clear groundwater ownership rights, scarcity rents frequently go unrecognized and are difficult to estimate. ${ }^{4}$ Ignoring scarcity rents means that the price of groundwater is too low and extraction is above the socially optimal level. In the absence of optimal dynamic management of common-pool groundwater resources, or, alternatively, in the presence of a competitive extraction regime, ${ }^{5}$ ignoring scarcity rents results in inefficient pricing and misallocation of the resource. How then can it be that the no-management (competitive) dynamic solution of groundwater exploitation is almost identical (in terms of derived social welfare) to the efficient management (optimal control) solution, as Gisser-Sánchez's effect (GSE) claims (Gisser and Sánchez, 1980a,b)?

GSE refers to a paradoxical empirical result, present and persisting in the dynamic solutions of groundwater exploitation under different extraction regimes, since 1980. Namely, although serious depletion of aquifers is a major threat to many freshwater ecosystems all over the world, the social benefits from managing groundwater extraction are numerically insignificant. Clearly, if GSE extends to a general rule, then the role and scope of water management are severely limited. This is even more evident when we take into consideration that implementing optimal extraction is not going to be costless. In this section, we critically review both the theoretical and empirical attempts to address GSE and discuss the potential for groundwater management for each of them. Moreover, we point at various misconceptions, inaccuracies, and omissions of the literature that can potentially reduce or eliminate this effect.

\subsection{Gisser-Sánchez Effect}

Problems of groundwater allocation have been studied in the context of the theory of mine by a number of economists including Milliman (1956), Renshaw (1963), and Kelso (1961). Then, Burt $(1964,1966,1967,1970)$ in a notable series of papers has drawn on principles of inventory management to derive decision rules for the optimal temporal allocation in a dynamic programming format. Extending Burt's work, Bredehoeft and Young (1970) studied the effects of different policy instruments that might correct the misallocation of commonly owned groundwater. They found that net benefits from groundwater management could amount to over $\$ 100$ per acre but noted that these benefits would decline with increases in interest rate. Brown and Deacon (1972) derived a formula for a tax that should be imposed on groundwater (pumped) in order to yield the optimal control solution. Then, Brown (1974) recognized the issue of congestion externality in aquifers with open-access characteristics and suggested a charging tax to accommodate this externality.

At the same time, other economists studied competitive solutions to the problem of temporal allocation of groundwater, where scarcity rents are completely

\footnotetext{
(C) Blackwell Publishing Ltd. 2004
} 
dissipated by users. Gisser and Mercado $(1972,1973)$ in an extension of work by Kelso (1961) and Cummings and McFarland (1973) showed that in a free market, farmers will pump until the aquifer reaches an unacceptable water level. When this point is reached, farmers will either import supplemental water or be restricted to use a smaller amount of water by being assigned water rights. Assuming, however, that at some future time farmers might reach the bottom of the aquifer anyway, they might want to consider optimal regulation of pumping at times earlier than the actual time of reaching the bottom. This argument poses an optimal control problem and warrants a solution that should be compared with the case of no control. This was the departure point for Gisser and Sánchez's work in 1980.

The basic model analyzed by Gisser and Sánchez is a simplified representation of the economic, hydrologic, and agronomic facts that must be considered for the irrigator's choice of water pumping. The irrigators benefit function is represented by

$$
\pi(t)=V[w(t)]-C[H(t)] w(t)
$$

where $\pi(t)$ denotes profits at time $t$. Net farm revenue from water use $w(t)$ (neglecting pumping costs) is denoted by $V(w)=\int_{0}^{w} p(x) \mathrm{d} x$, where $p(w)$ is the inverse demand function for water. $C(H)$ is the average and marginal pumping costs per acre-foot of water, where $H(t)$ is the height of water table above some arbitrary reference point at time $t$. The change in the height of the water table is given by differential equation (2), which represents the hydrologic state of the aquifer (or equivalently, the environmental constraint of the problem)

$$
\dot{H}=\frac{1}{A S}[R+(a-1) w], \quad H(0)=H_{0}
$$

where $R$ is constant recharge measured in acre feet per year, $a$ is the constant return flow coefficient which is a pure number, $H_{0}$ is the initial level of the water table measured in feet above sea level, $A$ is the surface area of the aquifer (uniform at all depths) measured in acres per year, and $S$ is the specific yield of the aquifer which is a pure number.

More precisely, the aquifer in Gisser and Sánchez's work is modeled as a 'bathtub', unconfined aquifer, with infinite hydraulic conductivity. ${ }^{6}$ The assumption of constant return flow in the presence of fixed irrigation technology suggests a constant rate of water application. The assumption of deterministic and constant recharge in conjunction with the assumption of constant return flow implies constant types of land use, independence of surface water and groundwater systems, and constant average rainfall. Moreover, sunk costs, replacement costs, and capital costs in general are ignored, and it is implicitly assumed that energy costs are constant. It is also implicitly assumed that the well pump capacity constraint is non-binding. Finally, exclusiveness in Gisser and Sánchez's model is achieved by assuming that only land overlying the aquifer can be irrigated,

(C) Blackwell Publishing Ltd. 2004 
i.e. the demand curve does not shift to the right over time. Overall, the explicit recognition of the assumptions behind GSE attempted in this paragraph indicates that the result should be used with caution on real aquifer systems.

Given the above hydroeconomic model, Gisser and Sánchez used a linear water demand function [estimated by Gisser and Mercado (1972) using parametric linear programming], hydrologic parameters that were considered realistic in the 1960s but have been revised since then, and a discount rate of $10 \%$, and simulated the intertemporal water pumpage for Pecos Basin in New Mexico, once under the assumption of no control and once under the assumption of optimal control. The results of their simulations were as follows:

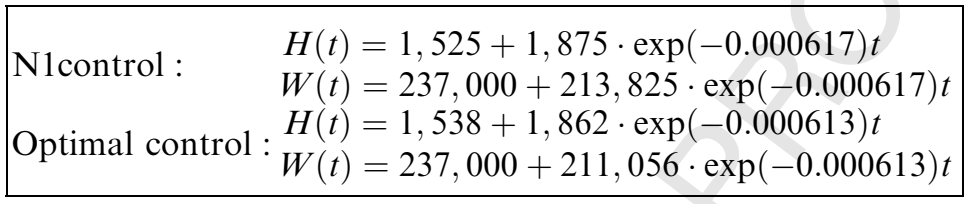

where $H$ and $W$ are the water table (measured in feet above sea level) and pumping (measured in acre feet per annum), respectively. Notice that the trajectories under the two regimes are almost identical. The wealth (present value of future income streams) was estimated at $\$ 309,990,007$ under no control and at $\$ 310,002,484$ under optimal control. The two figures are practically identical. This result led them to conclude that there is no substantive quantitative difference between socially optimal rules for pumping water and the so-called competitive rates; hence, the welfare loss from intertemporal misallocation of pumping effort is negligible. This conclusion amounts to GSE.

Solving analytically the model, Gisser and Sánchez concluded that if equation (2.3) is true, then the difference between the two strategies is so small that it can be ignored for practical consideration.

$$
\left[\frac{k C_{1}(a-1)}{A S}\right]^{2} \simeq 0
$$

In (2.3), $k$ is the decrease in demand for water per $\$ 1$ increase in price (i.e. the slope of the uncompensated demand curve for groundwater), $C_{1}$ is the increase in pumping cost per acre-foot per 1 foot decline in the water table, and $a$ and $A S$ are as given in equation (2.2). If (2.3) holds, then the rate of discount will practically vanish from the exponents of the optimal control problem. Thus, the exponents of the optimal control result will be practically identical with the exponents of the competition result. This analytical derivation implies that as long as the slope of the (uncompensated) groundwater demand curve is small relative to the aquifer's area times its storativity, GSE will persist.

The upshot of this result is obvious: if there is no quantitative difference between optimal and competitive rates of water pumping, then policy considerations can be limited to those which ensure that the market operates in a competitive fashion 
and concerns relative to rectifying common property effects are obviated. This is even more evident when we take into consideration that implementing optimal extraction is not going to be costless.

\subsection{Testing the Robustness of GSE}

The policy implications of GSE arose considerable concerns that led to a number of investigations which, at least in part, considered the robustness of the effect. Noel et al. (1980) found that control increases the value of groundwater in the Yolo basin in California by $10 \%$. Lee et al. (1981) found that control raised the net benefit of groundwater in the Ogallala basin by only $0.3 \%$. Feinerman and Knapp's (1983) empirical estimates of benefits from groundwater management in Kern County, California, did not exceed 10\%. Although Nieswiadomy (1985) found that groundwater management in the Texas High Plains would be unwarranted, he proceeded with a sensitivity analysis of present value profits using different slope and intercept values for the groundwater-demand curve. This analysis showed that benefits from groundwater management do not increase monotonically as the absolute value of the slope increases. A basic assumption in Gisser and Sánchez's model is the linearity of the demand curve for water. To study the relative importance of this assumption for GSE, Allen and Gisser (1984) compared optimal control and no-control strategies using a non-linear demand curve and the same data. This comparison confirmed for the case of the non-linear demand function what had been demonstrated by GSE for the case of a linear demand function.

Worthington et al. (1985), however, applied dynamic programming to a model of a confined aquifer underlying the Crow Creek Valley in southwestern Montana and found that the difference between the two regimes may not be trivial if the relationship between the average extraction cost and the water table level is not linear and/or if there exist significant differences in land productivity. When land is assumed to be homogeneous, the gross returns function with respect to water use tends to be nearly linear. But with greater heterogeneity in productivity, the returns function is more concave, and differences in the optimal use policy under a common property setting are more pronounced. ${ }^{7}$

\subsection{Allowing Variable Economic Relations and Endogenous Rates of Change}

Implicit in Gisser and Sánchez's model and in follow-up research are the assumptions of fixed economic relations (e.g. time-independent demand) and/or exogenous and constant rates of change (e.g. constant and fixed exogenous crop mix, constant crop requirements, fixed irrigation technology, ${ }^{8}$ constant energy costs, constant exogenous types of land use, and constant hydrologic conditions). As in any long-run study, however, projected results become more tenuous as the steady state is approached. Estimated benefit and cost functions used in the simulations of GSE may bear little relation to the actual benefit and cost functions when economic, hydrologic, and agronomic conditions are much different. More complex representations of increasing resource scarcity incorporate opportunities for adaptation to the rising resource prices that signal scarcity. In the long run,

(C) Blackwell Publishing Ltd. 2004 
adoption of new techniques, substitution of alternative inputs, and production of a different mix of products offer rational responses to increasing scarcity.

Kim et al. (1989) developed an $n$-stage optimal control model that incorporated the opportunity for adaptation to resource depletion. The model suggested two supplementary traits to a conventional intertemporal depletion path: the relative allocation of groundwater among irrigated crops and endogenous switch times describing an intertemporal cropping pattern. Both planning and common property equilibria were derived and compared empirically. From an application to Texas High Plains, the transition away from irrigation of sorghum to dryland agriculture occurs twice as fast when done optimally. However, benefits from groundwater management were as small as $1-3.7 \%$ as the interest rate varied from 5 to $2 \%$. Thus, GSE persists even when the opportunity of adaptation to resource depletion is incorporated in the analysis. Extending this model, Koundouri (2000) and Koundouri and Christou (2000) analyzed the optimal management of an aquifer, with stock-dependent extraction cost and a backstop substitute, facing multisector linear demands. Application to the Kiti aquifer in Cyprus demonstrates that the presence of a backstop technology diminishes the importance of management benefits $(3.8 \%)$, while its absence makes optimal control significantly welfare increasing $(409.4 \%)$. The latter result is attributed to the near-depletion state of the aquifer under consideration.

Brill and Burness (1994) found that a $2 \%$ annual demand growth led to significant divergence $(16.85 \%)$ in socially optimal versus competitive rates of groundwater pumping in Ogallala aquifer. In addition, their work supported existing evidence indicating that high social discount rates diminished the importance of (future) pumping cost externalities and produced a convergence between competitive and planning pumping rates. In a follow-up study, applied to Curry county, one of the five counties covered by the Ogallala aquifer, Burness and Brill (2001) considered a model with endogenous investment in irrigation technology. However, its numerical simulation revealed only a modest difference between benefits in the planning vis-à-vis the competitive solution. The welfare gains from more efficient water use are offset to some extent by inefficiencies in investment.

\subsection{Water Conflicts as Games}

During the last 20 years, economists have recognized that the theory of dynamic games provides the possibility of modeling the dynamic interactions involved in the allocation of natural resources and accounts for the fact that most externalities exhibit some form of structural time dependence. Game theory was also employed for the characterization of pumping behavior when the number of extracting players is small. Interesting inference on the robustness of GSE can be derived by comparing the steady-state groundwater level under (a) optimal control, (b) uncontrolled strategic interaction, and (c) uncontrolled non-strategic interaction.

\footnotetext{
(C) Blackwell Publishing Ltd. 2004
} 
Dixon (1989), Negri (1989), and Provencher and Burt (1993) discuss game theoretic models of pumping behavior under common property arrangements, where a firm's strategy is the groundwater extraction plan defining its behavior in each period of its planning horizon. An equilibrium in Nash strategies is a set of $(M)$ admissible groundwater extraction plans, the $j$ th element of which maximizes the value of groundwater to the $j$ th firm, given the other $(M-1)$ groundwater extraction plans in the set. The precise nature of the equilibrium depends on whether firms pursue path or decision-rule strategies. Nash equilibria in path strategies reflect the inclination of firms to take the extraction paths of the other firms exploiting the resource as given. Nash equilibria in decision-rule strategies reflect the inclination of firms to take the decision rules of the other firms exploiting the resource as given. The relevant equilibrium concept for decisionrule strategies ${ }^{9}$ is a type of Markov-Nash equilibria, in which the decision rules of firms at time $t$ are a function of only the current values of the state variables. As shown by Negri, path strategies capture only the pumping cost externality, whereas decision-rule strategies capture both the pumping cost externality and the strategic externality and exacerbate inefficient aquifer exploitation. In general, Provencher and Burt (1993) conclude that the steady-state groundwater reserves attained when firms use decision-rule strategies are bounded from below by the steady state arising when firms are myopic and from above by the steady state arising from optimal exploitation. ${ }^{10}$

\subsection{The Robustness of GSE Under a Private Property Rights Regime}

The remedy usually prescribed for the inefficiencies arising in common property resource extraction is central (optimal) control by a regulator, who uses taxes or quotas to obtain the efficient allocation of resource over time. When differential games are used, however, the instrument considered to implement the fullcooperative outcome is, apart from side payments, a tradable permit scheme. In the context of groundwater depletion, a number of writers suggested a similar institutional arrangement in which firms are granted an endowment of tradeable permits to the in situ groundwater stock, which they control over time. Each firm's bundle of permits represents its private stock of groundwater. This private stock declines due to groundwater pumping and increases to reflect the firm's share of periodic recharge. It also changes in response to the firm's activity in the market for groundwater stock permits, increasing when permits are purchased and decreasing when permits are sold. The market price for permits serves to allocate groundwater over time.

This particular regime is inefficient. Both the pumping cost externality and the risk externality (the latter arising in stochastic frameworks; see Section 4.2) persist after the allocation of permits. Moreover, this regime is time inconsistent. However, attempts to quantify the value of groundwater resource under both central (optimal) control and the private property rights regime indicate that groundwater privatization recovers most of the potential gain from management. In particular, in Provencher's (1993) programming model for Madera County,

(C) Blackwell Publishing Ltd. 2004 
California, this regime recovered $95 \%$ of the potential gain from management. Likewise, in a somewhat more complicated stochastic dynamic programming model for the same region, Provencher and Burt (1994) found that the private property rights regime recovers about $80 \%$ of the expected welfare gain from management. These findings may be attributed to the fact that this regime is more capable than others of exploiting the private information held by firms.

Significantly, although the private property rights regime recovers a relatively large proportion of the potential gain from groundwater management, this gain is relatively small and GSE remains robust. In particular, Dixon (1989) found that control raised the net benefit of groundwater in the Kern County, California, by $0.3 \%$, Provencher (1993) found that control raised the value of groundwater resource of Madera County, California, by 2-3\%, and Provencher and Burt (1994) by $4-5 \%$ for the same basin.

\subsection{GSE in Models of Conjunctive Use of Surface and Groundwater}

The first and most extensive studies of conjunctive use of surface water and groundwater are found in Burt (1964, 1966, 1967, 1970), where groundwater stocks are modeled as partially renewed by a stochastic process. Burt's analysis, however, modeled surface water and groundwater as substitute goods, abstracting from the problems associated with the lagged hydrologic effect present in a tributary aquifer. ${ }^{11}$ Burness and Martin (1988) were the first to develop an analytical economic model that focused primarily on the hydrologic link between surface and groundwater, by modeling the instantaneous rate of aquifer recharge caused by groundwater pumping, through river effects. They modeled such river effects as externalities which reinforced groundwater overpumping present due to the usual common property effects. Their conclusion was that optimal policy requires compensation to be paid for both river effects and aquifer depletion net of river effects. This work points to an additional externality created by groundwater pumping that can be corrected with appropriate management and potentially eliminate GSE by increasing management benefits. However, Burness and Martin did not proceed to an empirical estimation of these benefits.

Unfortunately, there exists no literature on models focusing primarily on the hydrologic link between ground and surface water and at the same time acknowledging the stochastic nature of surface water supplies. Instead, the literature that incorporates stochastic surface supplies into a groundwater model adopted Burt's (1964) framework. That is, surface water and groundwater are modeled as substitute goods, aquifers are not connected with surface water, and they only benefit from substantial natural recharge. One of the interesting issues that arises in this context is whether groundwater is more valuable in a stochastic setting than in a deterministic one.

Tsur (1990) and Tsur and Graham-Tomasi (1991) argued that economic intuition suggests that groundwater is undervalued in a deterministic setting, because such a setting fails to consider the role of the resource as a buffer against surface water drought. This intuition was supported by simulations for the

\footnotetext{
(C) Blackwell Publishing Ltd. 2004
} 
Negev Desert in Israel reported in Tsur and Graham-Tomasi (1991). The authors found that the buffer value of groundwater ranged from 5 to $84 \%$ of the total value of the resource, depending on extraction costs, the variability of surface water inflows, and aquifer size. Ignoring the aquifer's buffer value creates a risk externality. This externality ultimately arises because the income risk of water-using firms is affected by the total amount of groundwater stock available for pumping. Each additional unit of groundwater stock available for future consumption lowers income risk of all firms by increasing the buffer against risk, provided by the total amount of groundwater stock available for future pumping. But of course, in its decision-making, a firm considers only the private benefit of risk reduction and consequently fails to extract groundwater at the socially optimal rate.

Interestingly, however, the positive sign on the buffer value is an empirical result, not a theoretical one, which holds when the value function is convex in surface water supplies for all feasible values of groundwater stock. Although this is certainly plausible, and perhaps empirically prevalent, its violation does not violate the standard assumptions of the neoclassical paradigm. If we accept, however, that in the real world the buffer value of groundwater is usually positive, then deterministic analyses underestimate the in situ value of the resource and the benefits derived from its management. ${ }^{12}$

The question that remains to be answered, however, is whether the buffer value of groundwater is significant enough to eliminate GSE. The answer to this question turns on the relative magnitude of the buffer values under central (optimal) control and the common property arrangement. This is once again an empirical question. Knapp and Olson (1995) considered joint operation of a surface reservoir and groundwater aquifer, where reservoir inflows are stochastic and outflows can be used for irrigation or for recharge to the aquifer. By contrasting efficient groundwater use with common property use, they find that common property withdrawals are larger than efficient withdrawals for similar values of the state variables, resulting in significantly greater pumping depths in the steady state. Despite this, however, they found that the benefits from groundwater management are relatively small. Interestingly, however, optimal management reduced the variability of returns, which indicates that benefits may be larger under risk aversion. This let Knapp and Olson (1996) to construct an empirical model with risk aversion. However, their initial results show that the effects of risk aversion are very small for the groundwater management problem and that GSE prevailed.

\subsection{Modeling the Quality-Graded Quantity of Groundwater}

As it is obvious from Sections 2.1-2.6, the literature emphasizes the comparison between optimal pumping paths and common property outcomes. However, the value of water as a resource depends as much on the quantity available as on its quality. There exists an important bulk of literature that analyzes aquifer contamination in a pollution control perspective, giving emphasis to non-point 
pollution, namely when it is caused by irrigated agriculture. However, models of pollution control generally avoid the relationship between contamination and water-use decisions. The assessment of how much groundwater should be pumped is absent from these models, and water quality often enters the problem only as a minimum standard.

A general model of dynamic non-point pollution is presented by Xepapadeas (1992), using generic benefit and damage functions. Examples of dynamic contamination functions appear in Anderson et al. (1985) and Yadav (1997). Vickner et al. (1998) and Larson et al. (1996) developed models where fertilizer use and irrigation water are both control variables, yet water use is unlimited at a given price and its source is unspecified. Some related pollution problems have been discussed, such as the introduction of a catastrophic, pollution-related event that rules out future use, at least partially (Tsur and Zemel, 1997). However, these cases concentrate on the impact of uncertainty on exploitation policies, not on quantity/quality trade-offs. A group of papers that considers quality and quantity focuses on salinity problems (Tsur, 1991; Dinar, 1994; Xepapadeas, 1996; Zeitouni and Dinar, 1997; Dinar and Xepapadeas, 1998; Koundouri, 2000). Salinity, however, is a special type of quality problem, in the sense that degradation of the aquifer is not related to specific uses of inputs other than irrigation water.

Since additional externalities are present when quality is considered, it would be natural to suppose that intervention in such a case would yield a larger aquifer of better quality and possibly threaten the robustness of GSE. In an important paper, Roseta-Palma (2002) adds a quality variable to a typical resource extraction model and analyzes the role played by groundwater-quality-quantity interactions under optimal as well as private use. Roseta-Palma shows that the steady-state optimal groundwater stock always becomes higher in quantityquality than in quantity-only models. Furthermore, the private common property solution is characterized by smaller stock, lower quality or both. Thus, if there is intervention by a central planner, at least one of the two features of an aquifer will improve, although there is the possibility that such an improvement in one of them is achieved at the expense of the other. These results indicate the possibility of reducing GSE in quantity-quality models. Unfortunately, their empirical relevance has not been tested.

\subsection{Synopsis of Results}

Table 1 summarizes existing empirical evidence on the robustness of GSE. While different basins with various hydrologic characteristics and economic parameters were investigated, several general conclusions emerge. First, the possibility of negligible benefits from optimal groundwater management exists. Second, management benefits may differ from one basin to the next depending on the economic, hydrologic, and agronomic parameters. Third, there exist converging lines of evidence as to the sensitivity of management benefits. As indicated in Part $\mathrm{C}$ of Table 1, management benefits are quite sensitive to the slope of the demand function and interest rate, moderately sensitive to aquifer storativity and size, and

\footnotetext{
(C) Blackwell Publishing Ltd. 2004
} 


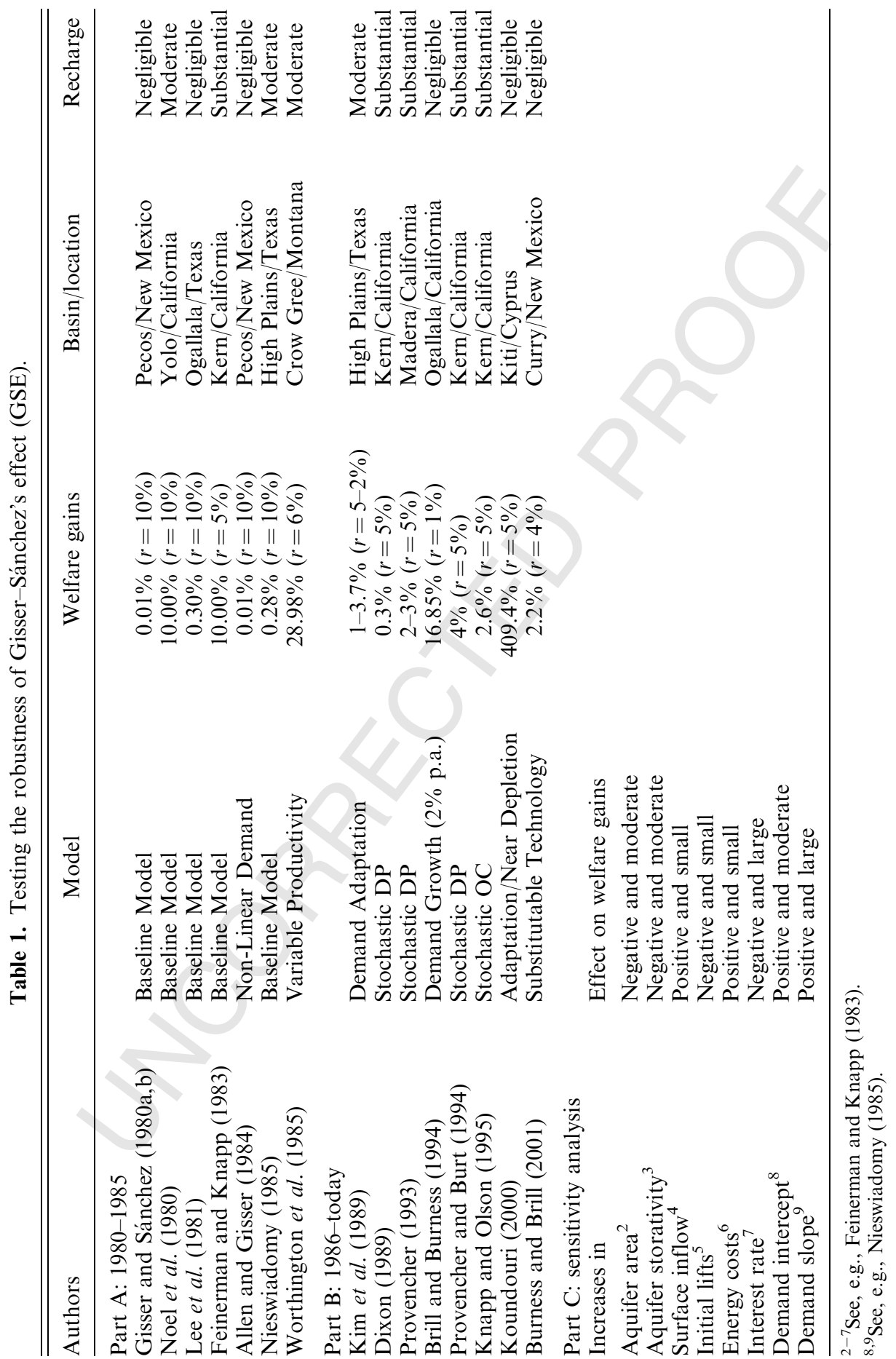


relatively insensitive to other parameters. Indeed, the sensitivity of GSE to the demand function is the central result that can be derived from reviewing this literature. However, this is not to say that there exists no need for groundwater management. On the contrary, in this section, we have suggested a number of circumstances that have rendered or may potentially render groundwater management significantly welfare increasing. These include non-linear extraction costs, heterogeneous land productivity, non-stationary demand, situations of near aquifer depletion, presence of 'river effects', accounting for risk averse extracting agents and adding quality considerations to a typical resource extraction model.

Pearce et al. (2003) indicate that uncertainty in the consumption growth rate and explicit recognition of the different range of individual preferences for the pure rate of time preference, which allows preferences for the present and for future generations to be included, might be incorporated into a model of future discount rates, both of which, independently, lead to discount rates which decline with time. The impact of declining discount rates as already shown in GSE-related sensitivity analyses (Table 1) will be increases in the benefits of groundwater preservation to future generations, which could potentially eliminate the GSE. Concern over the effects of current policy decisions on future generations is also intensified by the presence of suspected irreversibilities. Tsur and Zemel (1995) found that uncertainty concerning the occurrence of an irreversible effect increases the expected loss due to the event occurrence so much that it is not optimal to extract in excess of recharge. Thus, uncertainty about the effect of extraction on future availability of the resource does eliminate GSE.

The number of identified resolutions and possible paths for future research on GSE emphasizes the significance of developing realistic models for groundwater policy evaluation. Unfortunately, the difficulty of obtaining appropriate hydrologic and economic data and the computational burden arising as state and decision variables are added to a model remain barriers to the development of sophisticated dynamic optimization models. At best, current models provide only a general sense of the economic effects of various management prescriptions.

\section{Groundwater Demand}

The study of groundwater demand or willingness to pay (WTP) for groundwater is part of a strategy for the management of this resource, in the sense that it provides information about the effects of control variables on groundwater use. This section reviews the methods used for the derivation or estimation of a demand function for groundwater quality and quantity and points to the problems arising in such exercises. This discussion will enhance the reader's understanding of the limitations of the models reviewed in Section 2, as well as the difficulties involved in developing groundwater-pricing schemes or using other economic instruments for groundwater management, to be discussed in Section 4.

\footnotetext{
(C) Blackwell Publishing Ltd. 2004
} 


\subsection{The Demand for Groundwater Quantity}

\subsubsection{Programming Models}

The absence of observations over a wide range of prices has necessitated the use of programming approaches to estimate the elasticities of the derived demand for water. Demand estimates have been derived from 'shadow prices' obtained by computer simulations of profit-maximizing behavior. These computer simulations are based on the following general scheme. For a given price, they estimate the quantity of water that maximizes a farmer's profit. Water price variation induces different levels of optimal water quantities. This information is then directly used to derive the demand for irrigation water, while several assumptions concerning the crop-yield response function to irrigation water are made.

Many of these programming studies use linear programming (Gisser and Mercado, 1972; Shunway, 1973; Montginoul and Rieut, 1996) or the positive non-linear programming approach, which assumes that the cost of production is a quadratic function of acreage and reflects heterogeneity of land quality (Howitt et al., 1980; Bernardo et al., 1987; Howitt, 1995). Arc elasticities of demand from quadratic programming studies range from US\$ -0.20 /acre-foot to US\$ -0.97 /

7 acre-foot in California (Howitt et al., 1980) and US\$-0.22/acre-foot to US\$ -0.40 /acre-foot in the Columbia Basin of Washington (Bernardo et al., 1987). On the whole, irrigation demand curve estimates were found to be completely inelastic below a threshold price and elastic beyond (Shunway, 1973; Montginoul and Rieut, 1996; Garrido et al., 1997; Iglesias et al., 1998; Varela-Ortega et al., 1998; Bontemps and Couture, 2002). In general, this threshold price depends on climatic conditions and fluctuates between US\$0.13/acre-foot for a 'wet' year and US\$0.79/acre-foot for a 'dry' year.

A major criticism of the programming studies, however, is that pre-specified functions may not precisely represent the biological and physical processes of plant growth. Another drawback of the approach is that it ignores the impact of multiple applications of the water for each crop and gives more emphasis on crop patterns' shifts.

\subsubsection{Econometric Models}

When farm-level microeconomic data sets are available, the derived demand for irrigation groundwater can be estimated by econometric methods. The last decade produced such econometric evidence. Relevant estimates rely on actual farmer behavior and are usually based on cross-sectional water-use data. These estimations have commonly used dual input demand specifications and represent farmers as a multicrop production firm taking decisions concerning crop choices, crop-level long-run allocations of land, and water-use quantities in the short run. Recent studies established empirical evidence on the price elasticity of demand for irrigation water (Nieswiadomy, 1988; Ogg and Gollehon, 1989), 
quantified the effect of water price on irrigation development, irrigation technology choice, and irrigation technology demand (Caswell and Zilberman, 1985; Nieswiadomy, 1988; Negri and Brooks, 1990; Schaible et al., 1991), estimated the effect of reduced water entitlement on cropland allocation decisions (Moore and Negri, 1992), and used limited dependent variable methods to estimate crop choice, supply, land allocation, and water demand functions for field crops (Moore et al., 1994a,b).

The general conclusion of this literature is that producers adapt rationally to water-scarcity signals, although estimated irrigation water demand curves are price inelastic. Farm-level price elasticity of demand is highly inelastic in every region considered by Moore et al. (1994a,b): US\$ $-0.10 /$ acre-foot in the northwest, US\$ $-0.06 /$ acre-foot in the southwest, US\$ -0.03 /acre-foot in the Southern Plains, and US\$0.03/acre-foot in the Central Plains. Relevant econometric estimates are US\$-0.25/acre-foot in the Texas High Plains, estimated by Nieswiadomy (1988), and US\$-0.07/acre-foot to US\$-0.26/acre-foot for western irrigated agriculture, estimated by Ogg and Gollehon (1989). In general, farm-level price elasticities of water demand are moderately to highly inelastic, falling below US\$ $-0.40 /$ acre-foot. The price inelasticity of demand, however, may be attributed to the lack of data on crop-level water use. Moreover, these works do not use acreage-based models or fixed allocatable input models of water use; hence, they are not very efficient in explaining short-run decisions. Although it would be interesting to compare econometric elasticity estimates with those derived by programming methods, it has been shown by Shumway and Chang (1977) that conclusions typically should not be drawn about the quality of elasticity estimates when comparing results from programming and econometric methods.

This research was also extended to non-deterministic environments, which allowed the investigation of stochastic production responses (Day, 1965; Fuller, 1965; Anderson, 1973). A relatively new aspect of stochastic production models is the estimation of the effect of input choice on risk. ${ }^{13}$ This effect should be an important consideration when groundwater management policies are formulated, as there exist a number of possible cases where not only the marginal contribution of water use to the mean of output but also the marginal reduction in the variance of output should be considered. Groom et al. (2002) derive and discuss the implications of using an irrigation water quota under uncertainty and risk aversion. The difficulty in empirically specifying a model that takes into account farmers' risk preferences and stochastic production technology let Groom et al. to use Antle's $(1983,1987)$ flexible moment-based estimation approach. Using a microeconomic cross-section from the coastal agricultural area of Kiti, Cyprus, a region heavily relying on groundwater for irrigation, Groom et al. derived crop-specific risk attitudes (absolute Arrow-Pratt and downside risk aversion coefficients, as well as risk premia), as well as the impact of an irrigation water quota on input use and moments of profit. For the case of irrigation groundwater, the derived risk premium appears to be greater for the producers of vegetables $(19 \%$ of profit) than for the producers of cereals ( $7 \%$ of profit). The

(C) Blackwell Publishing Ltd. 2004 
greater dependency on irrigation water of vegetable growers was also emphasized through the results of quota simulation. The $10 \%$ quota was found to have a larger impact on this group of crops, leading to an increase in the risk premium. It was shown that neglecting risk, when assessing impacts of irrigation water quotas on input choices and expected profit, could provide misleading guidance to policy makers. Finally, Koundouri et al. $(2003 \mathrm{a}, \mathrm{b})$ show that farmers' risk preferences affect the probability of adopting new irrigation technologies, which results in economizing on groundwater extraction. This result provides evidence that farmers invest in new technologies as a means of hedging against input-related production risk, which should be taken into account when groundwater demand is estimated.

In closing this section on econometric approaches to deriving the demand for groundwater as an input in agriculture, we would like to point to the potential of using nonparametric econometric methods. The obsession with linearity in empirical economic analysis clearly does not stem from any strong prior economic theory. Nonparametric regression analysis seems to provide a compelling alternative to linear regression, allowing the data to determine the 'local' shape of the conditional mean relationship, thus avoiding the imposition of any parametric assumptions that might be invalid. To the best of our knowledge, this line of research is yet to be used in the estimation of groundwater demand.

\subsection{Deriving the Willingness to Pay for Groundwater Quality}

\subsubsection{The Hedonic Valuation Technique}

Groundwater quantity and quality may affect the productivity of land as an input in agricultural production. Where this is so, the structure of land rents and prices will reflect these environmentally determined productivity differentials. Hence, by using data on land rent or land value for different properties, one can in principle identify the contribution which the attribute in question makes to the value of (willingness to pay for) the traded good, land. This identifies an implicit or shadow price for quality (or even quantity) attributes of groundwater. The method commonly used to implement this approach is the hedonic technique pioneered by Griliches (1971) and formalized by Rosen (1974).

The earliest examples of hedonic methods applied to irrigation water valuation

10 were Milliman (1959) and Hartman and Anderson (1962). Their work anticipated most of the major developments of the hedonic method in the 1970s but predated the coining of the term 'hedonic'. More recent examples of empirical work on the relationship between land prices and groundwater access, mainly focusing on quality attributes of water, are Miranowski and Hammes (1984), Gardner and Barrows (1985), Ervin and Mill (1985), and King and Sinden (1988). These studies focus on valuing soil erosion and related effects on groundwater. Caswell and Zilberman (1985) find evidence that the introduction of modern land-qualityaugmenting irrigation technologies reduces the hedonic prices of land quality and water depth. Toell et al. (1990) compare sales of irrigated and non-irrigated lands

(C) Blackwell Publishing Ltd. 2004 
in order to measure the value of groundwater in the southern High Plains in the United States. They find that the value of groundwater is a significant part of irrigated farmland transaction prices, ranging from 30 to $60 \%$ of the farm sale price, depending on state. More specifically, water value estimates range from a high of about US\$9.50/acre-foot in New Mexico in 1983 to a low of US\$1.09/acre-foot in Oklahoma in 1986. Finally, Koundouri and Pashardes (2002) argue that hedonic valuation of quality attributes can be misleading when the assumption that these attributes are exogenous to sample selection is violated. In particular, they consider the simultaneity between hedonic valuation and sample selection in the context of a model of producer behavior and investigate empirically the case where land is demanded for use as an input either in agricultural production or in touristic development. The empirical analysis suggests that failing to correct for sample selection results in a biased valuation of the effect of groundwater salinity, while farmers' average marginal WTP for avoiding coast proximity and related groundwater salinization is estimated to be equal to US\$55.21/acre of land.

Some unrealistic assumptions of the hedonic technique have often been used to criticize values derived from relevant applications. For example, the technique assumes a perfectly competitive market for land, with rational and fully informed buyers and sellers. The observed land prices are assumed to represent the amount that a fully informed buyer would pay for the rights to a stream of net rents from land ownership, which is the discounted value of that stream of net rents. These assumptions might prove particularly unrealistic, especially in developing countries, and limit the applicability of the technique. ${ }^{14}$

\subsubsection{The Contingent Valuation Technique}

Many water-quality evaluation problems occur in a framework for which no value measures can be derived from observing individual choices through a market. This is mainly due to the public good aspect of groundwater quality. Other examples where actual consumer choices are non-observable are cases where the policy change is potential rather than actual. In such cases, respondents are offered conditions simulating a hypothetical market in which they are asked to express willingness to pay for existing or potential environmental conditions not registered on any market. The most common form of questioning on hypothetical futures is called the contingent valuation method (CVM). It involves asking people directly what they would be willing to pay contingent on some hypothetical change in the future state of the world (Mitchell and Carson, 1989).

Several recent studies have addressed the question of measuring damages from outbreaks of nonfatal waterborne diseases and of chemical pollutants. Harrington (1992) investigated two categories of benefits for study. The first category measures the willingness to pay to avoid acute illness. This raises questions of valuing the direct disutility of illness, medical expenses, and the value of lost time for work and leisure. The second category of benefits measures the reduced costs of averting behavior. These avoidance costs are the costs of actions

\footnotetext{
(C) Blackwell Publishing Ltd. 2004
} 
people take to reduce their exposure to environmental contaminants. Abdalla et al. (1992) evaluate chemical contamination of groundwater with averting expenditures ranging from 61,313.29 to US\$131,334.06 during an 88-week contamination period. Moreover, Smith and Desvouges (1986) describe several applications of CVM to the measurement of water quality-related benefits, although they do not consider any application directly relevant to groundwater.

As with any technique for measuring groundwater values, the advantages and disadvantages of CVM need to be considered when one chooses to use it. The principal advantage of the method is that it can potentially measure the economic benefits (or damages) of wide assortments of beneficial (or adverse) effects in a way that is consistent with economic theory. A major plus is the possibility of evaluating proposed, in addition to already available, goods and services. The technique can be addressed to values, such as non-use values, that cannot be successfully dealt with by any other valuation approaches. However, extreme care must go into the design and conduct of the survey. Questionnaires must be carefully formulated and tested, and if not a mail survey, interviewers must be carefully selected, trained and supervised. Econometric analysis of the data may present challenges. In particular, Mitchell and Carson (1989) evaluate three general types of potential sources of bias in CVM studies. One is that the questionnaire scenario can encourage strategic behavior - responses deliberately chosen to influence future provision of the resource characteristic being valued. A second type of misrepresentation of true preferences is compliance bias - a tendency to fit their responses to the perceived preferences of the interviewer or the surveying organization. A third and last general category of potential bias can result from scenario misspecification, which arises when the respondent fails to understand the scenario intended by the researcher. All these problems must be recognized and overcome.

Partly as a response to these problems, valuation practitioners are increasingly interested in alternative stated preference formats such as choice modeling (CM). $\mathrm{CM}$ is a family of survey-based methodologies (including choice experiments, contingent ranking, contingent rating, and paired comparisons) for modeling preferences for goods, which can be described in terms of their attributes and of the levels they take. Respondents are asked to rank, rate or chose their most preferred alternative. By including price/cost as one of the attributes of the good, willingness to pay can be indirectly recovered from people's rankings, ratings or choices. An excellent critical review of CM alternatives and investigation of their potential to solve some of the major biases associated with standard CVM is provided by Hanley et al. (2001). Although the literature is non-conclusive on this potential, empirical attempts to use such techniques for groundwater valuation could prove useful.

\section{Economic Instruments for Managing Groundwater}

Even while the fundamental question of the potential for groundwater management has not been completely resolved (see Section 2) and the estimation

(C) Blackwell Publishing Ltd. 2004 
of relevant demand and WTP functions is not easy (see Section 3), there are cases where some form of management is either clearly appropriate or politically expedient. In this light, it is worthwhile to consider alternatives to central control that are either non-intrusive, in the sense that they rely mostly on the private information held by firms, or relatively costless, or preferably both. In an attempt to summarize the vast literature on policy instruments that aim to induce producers to undertake changes toward improving their groundwater-related performance (see, e.g., reviews by Zilberman et al., 1997; Pearce and Koundouri, 2003; as well as theoretical and empirical papers by Shortle and Laughland, 1994; Shortle and Abler, 1997; Segerson and Miceli, 1998; Horan and Shortle, 2001; Shortle and Horan, 2001), in this section, we discuss the pros and cons of the major economic instruments suggested and used for managing both groundwater extraction and pollution. In doing so, we should keep in mind that an economic approach to groundwater depletion and pollution assumes that relevant costs and benefits can be measured, but as should be clear from previous sections, this is not easy. Moreover, it is not always clear who must comply with particular policy instruments, how their compliance, or performance, will be measured, and how to induce changes in behavior.

\subsection{Instruments for Managing Groundwater Extraction}

Theoretically, a tax can be used to restrain farmers from lowering the groundwater level below a certain standard. The effectiveness of a tax depends on the right estimation of the marginal tax level and on how risk averse farmers are with respect to damage from reduced water availability (both in quality and in quantity terms). A differentiated tax level has to be created, because of local differences in both the monetary value of reserves and vulnerability of the environment to changes in the groundwater level. An advantage of a tax is that it improves both economic and technical efficiency. Administrative costs are high, since a differentiated tax is not easy to control and monitor. The financial impact on affected parties depends on the restitution of revenues, which affects tax acceptability. Finally, there are practical implementation problems. It is hard to define a good basis for a tax. A volumetric tax on extraction is complicated, since it involves high monitoring costs. A tax on a change in the groundwater level is also complicated, because external and stochastic factors affect the level of groundwater, which is not uniform across any given aquifer. Charging water boards for lowering surface water levels will not influence an individuals farmer's behavior, but it will affect the strategy of groups of farmers represented in the governing body of water boards.

A subsidy is a reward for meeting a certain groundwater level, which is higher than the desired standard. Subsidies are not economically efficient; they create distortions and do not provide incentives for the adoption of modern technologies. Acceptability, however, is not an issue, since participation in subsidy schemes is voluntary and has positive financial implications. Implementation

(C) Blackwell Publishing Ltd. 2004 
problems are similar to those of a tax. ${ }^{15}$ As discussed in Sections 2.5 and 2.6.2, 11 another prescription economists offer in the face of demand-supply imbalances is the introduction of water markets (Anderson and Hill, 1997; Howitt, 1997). Such institutions have the capacity to rationalize water scarcity, both qualitatively and quantitatively. The potential promotion of efficiency from the creation of market institutions is well documented (Anderson and Hill, 1997; Zilberman et al., 1994). Once tradable permits are allocated, they can be traded subject to a set of prescribed rules. Although not fully efficient (see Section 2.5), tradable rights improve economic and technical efficiency, since the market determines the price of the right in a dynamic way. The high demand for administrative institutions is a major disadvantage. The financial impact on affected parties and related acceptability depends on the initial allocation of rights. The use of tradable rights for groundwater seems to be complicated in practice, since the impact of changes in the groundwater level on agricultural production and nature depends on location-specific circumstances. To avoid transferring rights among areas with heterogeneous characteristics, trading has to be restricted. That is, on the one hand, the market approach is embraced, but on the other hand, we need a trade institution for guided trading. ${ }^{16}$ A legal groundwater standard or quota can also be introduced. It will be effective if farmers face substantial monetary penalties for lowering the groundwater level below this standard or not adhering to the quota. Standards and quotas do not improve economic efficiency and do not introduce incentives to innovate. The financial impact is not always equitably distributed among affected parties, since there are differences in the vulnerability of areas to changes induced by these instruments. Differentiated standards and quotas, however, will pose a large burden on the administrative capacity. Usually, serious resistance is raised against the introduction of these policy instruments. Moreover, and as argued in Section 3.1.2, Groom et al. (2002) provide empirical evidence that attitudes toward risk are important when assessing the impact of these policies on production choices. That is, in the case of a groundwater standard or quota, deriving water-demand responses from a multi-input farmer decision model under risk has to account for the unobserved risk attitudes of farmers.

As stated by Khanna (2001, p. 291) 'The approach to environmental protection has been evolving from a regulation driven, adversarial 'government-push' approach to a more proactive approach involving voluntary and often 'businessled' initiatives to self-regulate their environmental performance'. In this spirit, another policy option for controlling groundwater use is voluntary agreements between farmers and government organizations. Participation in such control programs is encouraged by means of positive incentives (a restitution of taxes). Such programs try to convince farmers (through education) of the advantages of fine-tuned groundwater control. Voluntary agreements on controlling groundwater use are efficient, since they rely on specialized knowledge of participants about local conditions. When costs and benefits are not equitably distributed among affected parties, both parties can bargain about compensation payments. The allocation of such payments depends on the assignment of rights. Acceptability is not an issue, since it is a voluntary regime. Because of these advantages,

(C) Blackwell Publishing Ltd. 2004 
participation of farmers in planning and decision-making at the local level is becoming more common. ${ }^{17}$ The principle of allowing the individual members of agricultural organization and water boards to make decisions on issues that affect them rather than leaving those decisions to be made by the whole group, the so-called principle of subsidiary, is widely accepted.

\subsection{Instruments for Managing Non-Point Agricultural Pollution}

Focusing on groundwater pollution from non-point agricultural pollution from fertilizers and pesticides, Pearce and Koundouri (2003) compare a number of relevant policy options for controlling such pollution. One of them is public persuasion combined with technical assistance to facilitate changes in behavior. A more direct stimulus is setting product design or environmental performance standards to which farmers' must comply. This results in affecting farmers' choices of inputs and production, as well as pollution control practices, toward the socially optimal ones. An example of such direct regulations is pesticide registration, which restricts pesticides available to farmers and sets conditions of use.

Alternatively, farmers' behavior can be influenced toward the socially efficient solution through the use of economic incentives. Major options are taxes or liability for damages to discourage environmentally harmful activities, subsidies to encourage pro-environment behaviors, tradable permits to ration environmentally harmful activities, and contracts in which environmental authorities purchase specified pro-environmental actions. There are, however, a number of problems that need to be addressed. First, the low elasticities of demand for pesticides and fertilizers. These suggest that taxes will have little direct effect on reducing demand. This is, of course, a problem common to other environmental taxes such as the landfill tax and the aggregates tax. Evidence from Organization for Economic Cooperation and Development (OECD) countries (as documented by Pearce and Koundouri, 2003, Tables 2-5) suggests that such taxes may nonetheless have a 'signaling' effect on reducing demand, especially if farmers fear future rises. Possibly, more important is the indirect effects of reducing demand via information and research activities financed by hypothecated taxes.

A second problem that needs to be addressed is the difficulty in capturing as far as possible the geographic and product variation in damage. For pesticides, the product variation should be capable of being captured through toxicity weighted taxes, i.e. taxes would vary by commercial pesticide product. A single flat rate tax would appear to be inefficient, although it might be justified via its revenue-raising effects. However, the limited work available suggests that it is also very important to model cross-substitution between pesticides, which face different tax rates. Little information appears to be available on this issue but what there is is instructive. Geographical variation in ecosystem sensitivity to pesticides is probably not captured in a pesticide tax. This problem is common to fertilizer taxes: for fertilizers, the main cause of geographic variation in damage is ecosystem sensitivity. Beyond one experiment for Sweden, there appears to be no work comparable to that on pesticides which investigates the potential for geographically varying

(C) Blackwell Publishing Ltd. 2004 
taxes. Since the tax is an input tax, any variation would in any event set up an arbitrage market, blunting the point of the tax. Hence, a fertilizer tax would in all probability be blunter instrument than a toxicity-differentiated pesticides tax.

An additional issue is the extent to which, even if there are problems with these taxes, they perform better or worse than the alternatives. The main alternatives are some form of voluntary agreement and land zoning to cover application rates. Both can be judged inefficient, and the theoretical literature suggests that they are more inefficient than market-based approaches. Another concern is the practical scope for taxes, given that they would have to be superimposed on the increasingly complex legislative structures governing pesticides and, especially, nitrates. The issue is whether these instruments can induce 'beyond best practice' emissions. Finally, the possibility that some form of trading could take place with respect to manure loadings (and sewage sludge). A detailed life-cycle assessment would be required to avoid a situation where one environment problem is resolved by trading at the expense of creating another problem. Trading regimes appear to exist in the Netherlands for surplus manure, but their effectiveness is not known. Trading nutrient loadings also exist in limited form in some states of the United States of America.

In closing this section on economic instruments for groundwater management, we feel the need to point to the absence of economic instruments designed for quality-quantity management. Although admittedly a difficult issue, research should divert resources toward the design of such instruments, as in most arid and semi-arid regions, groundwater problems have both a quality and quantity dimension. Moreover, Shortle and Horan (2001), in an inclusive review of the main advances in the literature of non-point sources of pollution, identify a number of additional areas for further theoretical development. In particular, they point to the need for more research in addressing problems of moral hazard and adverse selection in the design on input-based instruments, monitoring and enforcement mechanisms, as well as behavior of individuals under collective penalty mechanisms. They also suggest that more theoretical work is needed for understanding dynamic incentive properties and the role of transaction costs. Finally, they point to the need for further empirical work to test the real-world importance of the stochastic nature of non-point pollution for policy design and performance, asymmetric information, and transaction costs.

\section{The Political Economy of Groundwater Management Reform}

Only slow progress has been made in implementing the instruments reviewed in Section 4 , in the form of coherent and practicable water management policies. In part, this is due to the complexity of issues surrounding groundwater management. Indeed, very few (if any) commodities possess as many idiosyncratic characteristics. Groundwater is a multifaceted good in time, space, and consumer preferences. There are also few resources that attract as much competition among its potential users, as does water in arid regions. Moreover, historical rights intersect with modern requirements to generate groundwater misallocation. In these circumstances, the standard

(C) Blackwell Publishing Ltd. 2004 
economic paradigm ${ }^{18}$ does not provide an adequate theoretical framework for the analysis of groundwater-related policies. The political economy literature to be surveyed in this section will suggest a core of conditions necessary for successful economic reforms. Our aim is to enable the reader to better understand the groundwater management reform process and the variables that affect it.

\subsection{Models of Groundwater Management Reforms}

As argued in Section 2, the fundamental open access problem and the boundaries of jurisdictions within groundwater systems lead to incomplete governance structures. Setting aside equity and public trust concerns and externality costs such as groundwater contamination and depletion must be weighted against the benefits of stimulating and promoting technology adoption, water conservation, and economic efficiency. These benefits are not achievable unless a well-developed legal and regulatory structure supports groundwater institutions. The regulatory instruments reviewed in Section 4 are not peculiar to groundwater, but their design in this context begs for creativity in institutional and governance structures. The typical aspects of well-articulated and transparent property rights - numerous well-informed buyers and sellers and physical transportability of water - are naïve and unhelpful to water administrators and governmental regulators.

Rausser (2000) has outlined two analytical frameworks that can be applied to water resource systems to achieve sustainable governance and institutional structures. The first is based on the Nash-Hrsanyi approach, and the second uses the non-cooperative model of multilateral bargaining developed by Rausser and Simon (1991). Both analytical frameworks admit specific features of water resource systems. The former framework imposes four fundamental axioms, while the latter is axiom free. Both frameworks recognize default options or disagreement outcomes and are driven by relative political influence and power.

The Nash-Harsanyi collective choice or bargaining models can be represented in reduced form by simple maximization problems. For every bargaining model, a solution map assigns to each feasible set (each set of feasible outcomes), the elements of this set that solve the model. Similarly, for each governance function, an analogous maximization map assigns to each feasibility set the element of the set that maximizes the given objective or governance function. Accordingly, the collective choice problem is transformed into the maximization of a single objective or governance function. Applications of this analytical framework to the structure of the political economy of water resources require modeling of the following major components: the physical water resource system, the economic structure, and the political power structure. The equilibrium solution for the hydrological political economy is then derived and compared with the socially optimal solution. The framework can be easily applied to systems involving conjunctive use of groundwater and surface water resources.

The framework developed by Rausser and Simon (1991), and known as the multilateral bargaining model, represents politics as a process by which compet-

13 ing interest groups negotiate a comprise agreement that reflects their relative

(C) Blackwell Publishing Ltd. 2004 
bargaining strengths. The approach considers a sequence of games with finite bargaining horizons and examines the limit points of equilibrium outcomes as the horizon is extended without bounds. These limit points are interpreted as a proxy for the equilibria of a bargaining game in which the number of negotiation rounds is finite but arbitrarily large. To illustrate the relevant experimental technique, Rausser (2000) discusses water resource allocations derived via simulations. The first simulation concerns the influence of the scope of the negotiations, while the second addresses the implications of heterogenous interest groups. Both simulations dramatically demonstrate the complexities of the multi-issue, multiparty bargaining framework in which water allocations need to be considered. Players' behaviors depend on the complex interactions and constraints imposed by both the behaviors of other payers and the institutional structure under which negotiations take place. One of these constraints is the existence of asymmetric information, to which we now turn.

\subsection{Information Deficiencies and High Transaction Costs of Necessary Regulations}

Although the water management literature has given little attention to the roles of asymmetric information and implementation costs, asymmetric information has recently become a central part of regulation theory. It has appeared under the heading of mechanism design or principal-agent theory (Laffont and Tirole, 1993), yet few applications to water regulation can be found (see, e.g., Loehman and Dinar, 1994; Smith and Tsur, 1997). Asymmetric information in groundwater regulation occurs when individual water intakes are known only to the users (i.e. when irrigation water is unmetered) or when the water-yield relationship involves parameters that are known to the grower but not to the regulator.

In the absence of implementation costs, and with perfect information, efficient pricing (and use of other policy instruments) is straightforward. Unobserved water intake alone does not pose a real problem, as water input can be deducted from the observed output (or other inputs) and priced indirectly through output. The problem of asymmetric information regarding production technology alone can be overcome by quantity-dependent water price schedules. Implementation costs alone may change the order of efficiency between the different pricing methods but add no conceptual difficulty otherwise. As argued by Tsur (2000), it is the combination of implementation costs and asymmetric information that requires the use of mechanism design theory to define efficient groundwater allocation and derive efficient price schedules.

\subsection{Political Dimensions of Reform and Experience from Groundwater Management Reforms}

The reform, design, and operation of groundwater-specific institutions, as well as all water-related institutions, are components of the mitigation process of the detrimental effects of transaction costs and asymmetric information. Institutional reforms, however, associated with changes in the distribution of power and 
benefits inevitably create considerable political opposition. The conventional view of institutional change is that either it is in the interests of economic efficiency or it merely redistributes income (Bromley, 1989). In this regard, interest groups form and attempt to influence the decision-making process so that the end result best serves their interests. Powerful political groups may slow, divert or even stop a desirable reform. The larger the number of interest groups, the more complicated the implementation process is likely to be.

Reasons for reform can vary according to the particular situation. However, in most cases, reform in a particular sector appears to be associated with a larger reform agenda. Reforms are often complicated by financial crises and low-cost recovery of the investment in water system. Such a situation is described in the case of Pakistan (Wambia, 2000), where the central government has to subsidize the budgets of the irrigation departments. Morocco is another case (Diao and Roe, 2000) where the public budget used to be the sole source of funding for water services provided mainly by irrigation districts. For the water sector to be targeted for reforms after elections when a new regime takes over is also common, as occurred in Andhra Pradesh in India (Oblitas et al., 1999). In such instances, the new regime should consider a broader perspective for reform reasoning and design that takes many other issues, raised in its platform, into account.

During both the design and the implementation stages of a reform, institutions that govern the sector have to be accounted for cautiously. As Bromley (2000) suggests, water-pricing and management reforms must be understood as part of the property regimes in which water users, water suppliers, and regulators are embedded. Existing bureaucracies have to be acknowledged and also engaged in the reform process, as has been the case in Brazil (Asad et al., 1999). The various interest groups play a major role in both the design and the implementation stages of the reform.

Because reforms change the status quo, one can expect both support for and opposition to reform agendas by various affected groups. As evident from worldwide experience, water-pricing and related institutional reforms generate active involvement by various interest groups that may be affected directly or indirectly. Geographical characteristics (Bromley, 2000), type of farm operation (McCann and Zilbermand, 2000), and farm size or wealth (Wambia, 2000) can also determine reactions to water reform. Moreover, an important explanation suggested

17 by Israel (1987) for support for or opposition to a reform is the ability of each of the affected groups to comprehend the various reform components. Therefore, to increase public support, a carefully planned dialogue should be initiated prior to launching the reform. Moreover, an important pillar of the reform agenda is the existence of a mechanism that addresses negative impacts of the reform on various sectors or that allows a fair share of the reform outcome to be allocated to powerless groups. As Haggard and Webb (1996), Krueger (1992), and Williamson (1994) have suggested, adequate compensation mechanism is an important part of a reform.

Moreover, international influence may be critical in the reform design and implementation process. Such an influence may take the form of pressure to

\footnotetext{
(C) Blackwell Publishing Ltd. 2004
} 
comply with a structure imposed by an international development institution as part of a large investment project. It can also take the form of incentives that come from regional cooperation through a trade agreement. For example, loan conditionalities are common features in structural adjustment projects that enhance agricultural policies (Krueger et al., 1991). Moreover, trade and other regional agreements that affect the agricultural sector may impose the restructuring of a system in one country as part of a condition for that country to join the regional agreement. An example of such regional pressure is the recent initiative in Europe known as the European Water Framework Directive. This is the central legislative piece that will guide European water policies for the coming decade. Water management reforms, as part of that directive, are expected to follow common rules that the member countries agreed to.

Finally, another issue that needs to be resolved in the international domain arises when two or more countries share a common aquifer. In such cases, the sovereignty of states precludes external enforcement of regulation, and as a result, international environmental agreements must be self-enforcing. However, game theoretic models explain why rewards and punishments imposed through the common property externality generally fail to tackle free riders and enforce full cooperation. For this reason, Wagner (2001) argues that environmental treaties need to include provisions that enhance incentives for participation such as transfers, sanctions, and linkages to other negotiation topics in international politics. Moreover, interactions with markets and governments, as well as the rules and procedures adopted in the negotiation process, do influence the design and the effectiveness of an international environmental agreement and need to be taken into account.

\subsection{Conditions for Successful Reforms}

18 Theory suggests (Krueger, 1992; Williamson, 1994; Haggard and Webb, 1996) several factors that have to be in place to ensure a successful reform outcome. A reform program will be successful if there is economic rationality in its design, political sensitivity in its implementation, and close and constant attention to political-economic interactions and social-institutional factors, so as to determine in each case the dynamics to follow.

The timing of a reform is also important. Two hypotheses (Williamson, 1994) the crisis hypothesis and the honeymoon hypothesis - are offered to account for the time factor in the reform-implementation process. The crisis hypothesis suggests that public perception of a crisis is needed to create conditions under which it is politically possible to undertake the reform. The honeymoon hypothesis suggests that it is easier to implement a reform immediately after a government takes office. Both hypotheses were proven to be valid, depending on the particular country case study.

The recommendation for an implementation method is less clear in the literature. However, some of the studies in Williamson (1994) suggest a relationship between a country's political style and the pace of its reform implementation. Whereas strong regimes or dictatorships may be able to implement swift reforms,

(C) Blackwell Publishing Ltd. 2004 
Williamson suggests that weaker regimes or democratic regimes use a gradual approach amended by a series of supportive and compensatory programs. In many cases, water-pricing reforms have been implemented on a subsectoral basis, for example, reforming only the irrigation subsector and leaving urban and industrial sectors unchanged. However, as Howe and Koundouri (2003), Groom et al. (2003a,b), Bromley (2000), and Diao and Roe (2000) suggest, water-pricing reforms that are designed and implemented in a comprehensive manner have a greater likelihood of succeeding. Because the irrigation sector in many countries accounts for both large volumes of the available water and a substantial share of employment or gross domestic product, reforming the irrigation subsector in isolation from the rest of the economy may be unsustainable.

Williamson and Haggard (1994) suggest additional factors to help implement successful reforms. These include the commitment of a strong government; the creation of an independent, dedicated, and professional reform implementation team; the use of the media to convey the reform messages; the use of alternative policy measures to allow for sustainable reform consequences; an efficient reform program leading to low transition costs; the implementation of safety nets for the poor and those who were ignored; and the introduction of compensation packages for those who may be hurt by the new policies.

Can we predict the outcomes of water-pricing reforms? Is a well-planned reform more likely than a less-planned one to succeed? Is the extent of the reform a good predictor of the likelihood that it will achieve its objectives? Crisp and Kelly (1999), using analyses of structural adjustment reforms in 16 Latin American countries, show that multi-objective reforms, even if thoroughly implemented, sometimes fell short of key objectives. Is the water sector different? The evidence presented in Dinar (2000) suggest that the water sector is no different from other sectors when it comes to implementing reforms. Although water has several characteristics that make it different from other commodities, water-pricing reforms are affected by the same factors as reforms in other sectors. However, some factors, such as the power of ownership effect, may have a lager impact on the water sector than on other sectors.

Our experience from consulting water-pricing reforms in many developed and developing countries indicates that water-pricing reforms should be launched after extensive public awareness campaigns. Reformers should communicate a clear economic rationale, develop a broad reform agenda, adjust to institutional and political reality, and take account of traditional customs and social structures. Successful reform programs must include compensation mechanisms negotiated with stakeholders. Reformers should precisely identify their objectives. Reforms should be well prepared, because once they are implemented, they are hard to modify. Moreover, the implementing agency must be sensitive to political events when putting the reforms in place. The agency should package and sequence the reform components to minimize opposition. It should be aware of other political events, such as elections, seek external support, and mobilize supportive stakeholders as much as possible. In addition, gains from reforms have to be shared and pricing reforms should acknowledge asymmetric upstream

(C) Blackwell Publishing Ltd. 2004 
and downstream externalities, as well as the differences and interrelationships between groundwater and surface water. Reformers should acknowledge the need for a set of institutions and not impose a generic process for reform implementation, and the social objective function should include the power and transaction costs associated with reform implementation.

In closing this section, we want to point to the need for more research into the following issues. First, collection of more data about ongoing water-pricing reforms, especially in the form of case studies. Second, research should focus on several theoretical issues, such as defining and measuring the extent of reforms, defining and measuring the reform objectives' achievement, and defining the status quo conditions and their impact on reform implementation.

\section{Conclusion}

In this paper, we attempted to bring the most advanced and appropriate tools to bear on the issue of resource allocation involving groundwater. Our objective was to demonstrate the state of the art in the literature on ways to think about this complex resource and to deal with the important economic issues emanating from its complexity. There remain to be accomplished large amounts of substantive research on the topic of efficient groundwater resource management. We believe that this paper helps summarize existing results on which future research will be based.

\section{Acknowledgements}

I thank the European Commission, DG XII, Cambridge Commonwealth Trust, and Peterhouse of the University of Cambridge for financial support. I am also indebted for a number of inspiring discussions with Paul Seabright, Alistair Ulph, David Newbery, Anastasios Xepapadeas, Charles Howe, Jacov Tsur, Ariel Dinar, and David Zilberman. The usual disclaimer applies.

\section{Notes}

1. These groundwater velocities compare to rates of up to $1 \mathrm{~m}$ per second for river flows.

2. The buyer can either purchase water rights covering an existing source, with extraction $\operatorname{cost}\left(q_{\mathrm{Gt}} \cdot c\right)$ or develop the backstop at $\operatorname{cost}\left(q_{\mathrm{Gt}} \cdot \bar{p}\right)$. Thus, for the incremental source at capacity $\left(q_{\mathrm{Gt}}\right)$, the buyer's maximum willingness to pay for existing rights is represented by the distance $c \bar{p}$.

3. The basis for determining owners' reservation price is the awareness that if today's rate of use increases by one unit, the buyer will incur sooner the higher costs of supramarginal wells.

4. See, e.g., Groom et al. (2003a,b), Koundouri (2003), Koundouri and Xepapadeas (2003a,b), and Koundouri and Pashardes (2002).

5. Competitive behavior need not be myopic. The problem is not with the market mechanism but with the property rights institution. However, this misuse seems to be fairly commonplace in this literature, so we will not interfere with its perpetuation and hope that readers will suffer this imprecision.

(C) Blackwell Publishing Ltd. 2004 
6. Infinite hydraulic conductivity implies that the aquifer will never dry up, irrespective of groundwater extraction rates, which is equivalent to the assumption of a bottomless aquifer. Gisser and Sánchez justified their adoption of the bottomless aquifer assumption by arguing that it is implied by the standard assumption in the literature that time goes to infinity. However, if this is not the case, a steady-state solution might not be reached. Moreover, Zimmerman (1990) showed that the optimal pumping rate can be substantially lower when the hydraulic conductivity is small enough to result in a significant cone of depression around the well.

7. Hence the need for more theoretical work to resolve an asymmetric groundwater pumping differential game, where the differences in land productivity are taken into account.

8. Notable exceptions are Burness and Brill (1992) and Shah et al. (1995) who considered endogenous irrigation technology choice.

9. Nash equilibria in path strategies are not good approximations of extracting behavior. It is doubtful that under the common property regime the firms exploiting the groundwater resource will jointly commit to a set of path strategies, especially in light of the stochastic processes, which place a premium on flexibility in decision making. Given that firms usually base their extraction decisions on the observed state of nature, decision rules seem to be a more realistic description of actual behavior.

10. Following Tsutsui and Mino (1990) in the field of industrial economics or Wirl (1994) in the field of environmental economics, Rubio and Casino (2003) examined whether there exist feedback equilibria which approach the cooperative solution more than path strategies. Their findings show that strategic behavior (i.e. feedback equilibria) plays against the efficiency of private exploitation, but they also confirm the robustness of GSE.

11. A tributary aquifer is characterized by a groundwater stock that is hydrologically connected to a body of surface water. In such an aquifer, surface water may recharge the underground aquifer, or groundwater may supplement surface flows depending upon hydrological conditions.

12. Moreover, Provencher and Burt $(1993,1994)$ argued that managing groundwater by adopting the regime of private tradeable water permits may generate considerable welfare in a stochastic framework by providing opportunities for risk management. The negative correlation between production income and income from groundwater stock permits (i.e. water scarcity reduces production income but increases the price of groundwater stock permits, thereby increasing stock trade income) provides a means of risk management not available under central control. This result suggests the potential for welfare gains from 'smoothing' surface water inflows. Note, however, that this rationale is diminished by the presence of groundwater, which is itself a source of water consumption 'smoothing'. In this context, the buffer value of groundwater is the welfare gain from postponing (perhaps indefinitely) those inflow-smoothing surface water projects which would prove economical to undertake immediately in the absence of groundwater.

13. The traditional approach (theoretical and empirical) to evaluating the impact of the choice of inputs on production risk makes implicit, if not explicit, assumptions to the effect that inputs increase risk (see, e.g., Batra, 1974; Stiglitz, 1974; Bardhan, 1977). Just and Pope $(1978,1979)$ who identified this restrictiveness proposed a more general stochastic specification of the production function which allows inputs to be either risk-increasing or risk-decreasing. Moreover, Koundouri and Nauges (2003) show that 
in the presence of uncertainty and selection bias, the latter introduced by the endogeneity of qualitative characteristics of inputs in crop choice, correcting for risk considerations (à la Just and Pope, 1979, 1979), but not selection bias, solves neither of these problems. Finally, Antle $(1983,1987)$ has shown that Just and Pope's approach does restrict the effects of inputs across the second and higher moments, in exactly the same way traditional econometric models do across all moments. To overcome this restriction, Antle introduced a moment-based approach, which begins with a general parameterization of the moments of the probability distribution of output, which allows more flexible representations of output distributions and allows the identification of risk parameters.

14. In Section 5, we discuss the limitations of using models based on such assumptions, in the identification of efficient and sustainable groundwater management policies.

15. Farmers often receive payments for drastic income losses due to lower groundwater levels. These payments are called subsidies, which is a misleading term, since these payments do not provide conservation incentives but aim to balance financial implications on affected parties. Whether this is justified depends on the allocation of rights to groundwater levels.

16. Although not many groundwater markets exist, an example of an active one is run by the Edwards Aquifer Authority (http://www.edwardsaquifer.org) in Texas, with permits being leased or sold through the 'Water Trust'.

17. For an extensive survey of the theoretical literature on the economic efficiency of voluntary relative to non-voluntary approaches for environmental protection, as well as empirical findings on the factors motivating self-regulation by firms and its implications for their economic and environmental performances, see Khanna (2001).

18. This paradigm (market model) is supported, in most cases, by well-defined behavioral theory of the parties involved, which is based on individuals' rational behavior, on availability of full information with no transactions cost, on a preference set that depends only on individual consideration, on maximization of welfare, and on freedom of choice. Within such a framework, economists and water experts are comfortable with identifying efficient allocation of groundwater over time and space and devising water-pricing schemes (or alternative economic instruments).

\section{References}

Abdalla, C. W., Roach, B. A. and Epp, D. J. (1992). Valuing environmental quality changes using averting expenditures: an application to groundwater contamination. Land Economics 68(2): 163-169.

Allen, R. C. and Gisser, M. (1984). Competition versus optimal control in groundwater pumping when demand is nonlinear. Water Resources Research 20: 752-756.

Anderson, J. (1973). Sparse data, climatic variability, and yield uncertainty in response analysis. American Journal of Agricultural Economics 55: 77-82.

Anderson, T. L. and Hill, P. J. (eds.) (1997). Water Marketing - The Next Generation. Lanham, MD: Rowman \& Littlefield.

Anderson, G., Opaluch, J. and Sullivan, W. M. (1985). Nonpoint agricultural pollution: pesticide contamination of groundwater supplies. American Journal of Agricultural Economics 67: 1238-1246.

Antle, J. (1983). Testing the stochastic structure of production: a flexible moment-based approach. Journal of Business and Economic Statistics 1: 192-201. 
Antle, J. (1987). Econometric estimation of producers' risk attitudes. American Journal of Agricultural Economics 509-522.

Asad, M., Azevedo, G., Kemper, K. and Simpson, L. (1999). Management of water resources: bulk water pricing in Brazil. Technical Paper no. 432. Washington, DC: World Bank.

de Azevedo, L. G. T. and Asad, M. (2000). The political process behind the implementation of bulk water pricing in Brazil. In A. Dinar (ed.), The Political Economy of Water Pricing Reforms. Oxford University Press.

Bardhan, P. (1977). Variations in forms of tenancy in a peasant economy. Journal of Development Economy 4: 105-118.

Batra, R. (1974). Resource allocation in a general equilibrium model of production under uncertainty. Journal of Economic Theory 8: 50-63.

Becker, N., Zeitouni, N. and Zilberman, D. (2001). Issues in the economics of water resource. In H. Folmer and T. Tietenberg (eds.), Yearbook of Environmental and Resource Economics. Routledge.

Bernardo, D. J., Whittlesey, N. K., Saxton, K. E. and Bassett, D. L. (1987). An irrigation model for management of limited water supplies. Western Journal of Agricultural Economics 12: 164-173.

Bontemps, C. and Couture, S. (2002). Evaluating irrigation water demand. In P. Pashardes, T. Swanson and A. Xepapadeas (eds.), Current Issues in the Economics of Water Resources Management: Theory, Applications and Policies. Kluwer.

Bredehoeft, J. D. and Young, R. A. (1970). The temporal allocation of ground water - a simulation approach. Water Resources Research 6: 3-21.

Brill, T. S. and Burness, H. S. (1994). Planning versus competitive rates of groundwater pumping. Water Resource Research 30(6): 1873-1880.

Bromley, D. W. (1989). Institutional change and economic efficiency. Journal of Economic Issues 23(3): 735-759.

Bromley, D. W. (2000). Property regimes and pricing regimes in water resource management. In A. Dinar (ed.), The Political Economy of Water Pricing Reforms. Oxford University Press.

Brown, B. Jr. (1974). An optimal program for managing common property resources with congestion externalities. Journal of Political Economy 82: 163-173.

Brown, G. and Deacon, R. (1972). Economic optimization of a single cell aquifer. Water Resources Research 8: 552-564.

Burness, H. S. and Brill, T. C. (1992). The role for policy in common pool groundwater use. Resource and Energy Economics 23: 19-40.

Burness, H. S. and Brill, T. C. (2001). The role for policy in common pool groundwater use. Resource Energy Economics 23(1): 19-40.

Burness, H. S. and Martin, W. E. (1988). Management of a tributary aquifer. Water Resources Research 24: 1339-1344.

Burt, O. R. (1964). Optimal resource use over time with an application to groundwater. Management Science 11: 80-93.

Burt, O. R. (1966). Economic control of ground water reserves. Journal of Farm Economics 48: 632-647.

Burt, O. R. (1967). Temporal allocation of groundwater. Water Resources Research 3: 45-56.

Burt, O. R. (1970). Groundwater storage control under institutional restrictions. Water Resources Research 6: 1540-1548.

Caswell, M. and Zilberman, D. (1985). The choice of irrigation technologies in California. American Journal of Agricultural Economics 67: 224-234.

Crisp, B. F. and Kelly, M. J. (1999). The socio-economic impacts of structural adjustments. International Studies Quarterly 43(3): 533-552.

Cummings, R. G. and McFarland, J. W. (1973). Groundwater management and salinity control. American Journal of Agricultural Economics 56: 830-836. 
Day, R. (1965). Probability distribution of field crop yields. Journal of Farm Economics 47: $713-741$.

Diao, X. and Roe, T. (2000). The win-win effect of joint water market and trade reform on interest groups in irrigated agriculture in Morocco. In A. Dinar (ed.), The Political Economy of Water Pricing Reforms. Oxford University Press.

Dinar, A. (1994). Impact of energy cost and water resource availability on agriculture and groundwater quality in California. Resource and Energy Economics 16: 47-66.

Dinar, A. (2000). The Political Economy of Water Pricing Reforms. Oxford University Press.

Dinar, A. and Xepapadeas, A. (1998). Regulating water quantity and quality in irrigated agriculture. Journal of Environmental Management.

Dixon, L. S. (1989). Models of groundwater extraction with an examination of agricultural water use in Kern County, California. PhD Dissertation, University of California, Berkeley.

Ervin, D. E. and Mill, J. W. (1985). Agricultural land markets and soil erosion: policy relevance and conceptual issues. American Journal of Agricultural Economics December: 938-942.

Feinerman, E. and Knapp, K. C. (1983). Benefits from groundwater management: magnitude, sensitivity, and distribution. American Journal of Agricultural Economics 65: $703-710$.

Fuller, W. (1965). Stochastic fertilizer production functions for continuous corn. Journal of Farm Economics 47: 105-119.

Gardner, K. and Barrows, R. (1985). The impact of soil conservation investment on land prices. American Journal of Agricultural Economics December: 943-947.

Garrido, A., Varela-Ortega, C. and Sumpsi, J. M. (1997). The interaction of agricultural pricing policies and water districts' modernization programs: a question with unexpected answers. Paper presented at the 8th Conference of the European Association of Environmental and Resource Economists, Tilburg, The Netherlands, June 28-29.

Gisser, M. (1983). Groundwater: focusing on the real issue. Journal of Political Economy 91: 1001-1028.

Gisser, M. and Mercado, A. (1972). Integration of the agricultural demand functions for water and the hydrologic model of the Pecos Basin. Water Resources Research 8(6): $1373-1384$.

Gisser, M. and Mercado, A. (1973). Economic aspects of ground water resources and replacement flows in semiarid agricultural areas. American Journal of Agricultural Economics 55: 461-466.

Gisser, M. and Sánchez, D. A. (1980a). Some additional economic aspects of ground water resources replacement flows in semi-arid agricultural areas. International Journal of Control 31(2): 331-341.

Gisser, M. and Sánchez, D. A. (1980b). Competition versus optimal control in groundwater pumping. Water Resources Research 31: 638-642.

Griliches, Z. (ed.) (1971). Price Indexes and Quality Change. Cambridge, MA: Harvard University Press.

Groom, B., Koundouri, P., Nauges, C. and Alban, T. (2002). Stochastic technology and risk attitudes in agricultural production. Paper presented at the Second World Congress of Environmental and Resource Economists, 2002, June 24-27, Monterey, CA, USA.

Groom, B., Koundouri, P. and Swanson, T. (2003a). The watershed economics management approach: an application to Cyprus. In P. Koundouri, P. Pashardes, T. Swanson and A. Xepapadeas (eds.), Economics of Water Management in Developing Countries: Problems, Principles and Policies. Edward-Elgar. ISBN: 184376122X.

Groom, B., Koundouri, P. and Swanson, T. (2003b). Integrated resource management in Cyprus: introducing and applying a new methodology. In R. Brouwer and D. Pearce

30 (eds.), The Economics of Water. The Netherlands: Kluwer (forthcoming). 
Haggard, S. and Webb, S. B. (1996). Voting for Reform. New York: Oxford University Press. Hanley, N., Mourato, S. and Wright, R. E. (2001). Choice modelling approaches: a superior alternative for environmental valuation? Journal of Economic Surveys 15(3): 435-462.

Harrington, D. H. (1992). Management issues relating to policy analysis. In M. C. Ahearn and U. Vasavada (eds.), Costs and Returns for Agricultural Commodities: Advances in Concepts and Measurement, pp. 43-56. Boulder, CO: Westview Press.

Hartman, L. M. and Anderson, R. L. (1962). Estimating the value of irrigation water from farm sales in Northeastern Colorado. Journal of Farm Economics 44(1): 207-213.

Horan, R. and Shortle, J. (2001). Environmental instruments for agriculture. In J. Shortle and D. Abler (eds.), Environmental Policies for Agricultural Pollution Control, pp. 19-66. Wallingford, CT: CAB International.

Howe, C. and Koundouri, P. (2003). The economics of water management in developing countries principles and policies. In P. Koundouri, P. Pashardes, T. Swanson and A. Xepapadeas (eds.), Economics of Water Management in Developing Countries: Problems, Principles and Policies. Edward-Elgar. ISBN: 184376122X.

Howitt, R. (1995). Positive mathematical programming. American Journal of Agriculture 77: $329-342$.

Howitt, R. (1997). Market based conflict resolution. In Proceedings of the Rosenberg International Forum on Water Policy. Davis, CA: University of California, Water Resources Center.

Howitt, R. E., Watson, W. D. and Adams, R. M. (1980). A reevaluation of price elasticities for irrigation water. Water Resources Research 16: 623-628.

Iglesias, E., Garrido, A., Sumpsi, J. and Varelaortega, C. (1998). Water demand elasticity: implications for water management and water pricing policies. Paper presented the World Congress of Environmental and Resource Economists, Venice, June 26-28.

Just, R. and Pope, R. (1978). Stochastic representation of production functions and econometric implications. Journal of Econometrics 7: 67-86.

Just, R. and Pope, R. (1979). Production function estimation and related risk considerations. American Journal of Agricultural Economics 276-284.

Kelso, M. M. (1961). The stock resource value of water. Journal of Farm Economics 43(5): $1112-1129$.

Khanna, M. (2001). Non-mandatory approaches to environmental protection. Journal of Economic Surveys 15(3): 291-324.

Kim, C. S., Moore, M. R. and Hanchar, J. J. (1989). A dynamic model of adaptation to resource depletion: theory and an application to groundwater mining. Journal of Environmental Economics and Management 17: 66-82.

King, D. A. and Sinden, J. A. (1988). Influence of soil conservation on farm land values. Land Economics 64(3): 242-255.

Knapp, K. C. and Olson, L. J. (1995). The economics of conjunctive groundwater management with stochastic surface supplies. Journal of Environmental Economics and Management 28: 340-356.

Knapp, K. C. and Olson, L. J. (1996). Dynamic resource management: intertemporal substitution and risk aversion. American Journal of Agricultural Economics 78: 1004-1014.

Koundouri, P. (2000). Three approaches to measuring natural resource scarcity: theory and application to groundwater. PhD Thesis, Department of Economics, Faculty of Economics and Politics, University of Cambridge.

Koundouri, P. (2003). Contrasting different methodologies to deriving natural resource scarcity rents. In P. Koundouri, P. Pashardes, T. Swanson and A. Xepapadeas (eds.), Economics of Water Management in Developing Countries: Problems, Principles and Policies. Edward-Elgar. ISBN: 184376122X.

Koundouri, P. and Christou, C. (2000). Dynamic adaptation to resource scarcity with backstop availability. Paper presented at the tenth annual conference of the

(C) Blackwell Publishing Ltd. 2004 
Euro-Pean Association of Environmental and Resource Economists, June 2000, Rethymnon.

Koundouri, P. and Nauges, C. (2003). Production function estimation with risk and selectivity considerations: an application to crop-choice. Paper presented at the Twelfth Annual Conference of the European Association of Environmental and Resource Economists, June 2003, Bilbao, Spain.

Koundouri, P. and Pashardes, P. (2002). Hedonic price analysis and selectivity bias: water salinity and demand for land. Environmental and Resource Economics 23(2): 45-56.

Koundouri, P. and Xepapadeas, A. (2003a). Measuring natural resource scarcity: a distance function approach. Water Resource Research.

Koundouri, P. and Xepapadeas, A. (2003b). A new methodology to measuring groundwater scarcity: theory and application. In P. Koundouri, P. Pashardes, T. Swanson and A. Xepapadeas (eds.), Economics of Water Management in Developing Countries: Problems, Principles and Policies. Edward-Elgar. ISBN: 184376122X.

Koundouri, P., Nauges, C. and Tsouvelekas, V. (2003a). Endogenous technology adoption under production risk: theory and application to irrigation technology. Paper presented at the Twelfth Annual Conference of the European Association of Environmental and Resource Economists, June 2003, Bilbao.

Koundouri, P., Pashardes, P., Swanson, T. and Xepapadeas, A. (2003b). Economics of Water Management in Developing Countries: Problems, Principles and Policies. Edward-Elgar. ISBN: 184376122X.

Krueger, A. O. (1992). The Political Economy of Agricultural Pricing Policy. Vol. 5: A Synthesis of the Political Economy in Developing Countries. Baltimore, MD: The Johns Hopkins University Press.

Krueger, A., Schia M. and Valdes, A. (eds.) (1991). The Political Economy of Agricultural Pricing Policy. Vols. 1-4. Baltimore, MD: The John Hopkins University Press.

Laffont, J. J. and Tirole, J. (1993). A Theory of Incentives in Procurement and Regulation. Cambridge, MA: MIT Press.

Larson, D., Helfand, G. and House, B. (1996). Second-best tax policies to reduce nonpoint source pollution. American Journal of Agricultural Economics 78: 1108-1117.

Lee, K. C., Short, C. and Heady, E. O. (1981). Optimal groundwater mining in the Ogallala Aquifer: estimation of economic losses and excessive depletion due to commonality. Unpublished manuscript. Center for Agricultural and Rural Development, Iowa State University.

Loehman, E. and Dinar, A. (1994). Cooperative solution of a local externality problem: a case of mechanism design applied to irrigation. Journal of Environmental Economics and Management 26: 235-256.

Love, H. A. and Buccola, S. T. (1999). Joint risk preference-technology estimation with a primal system: reply. American Journal of Agricultural Economics 81: 245-247.

McCann, R. J. and Zilbermand, D. (2000). Governance rules and management decisions in California's agricultural districts. In A. Dinar (ed.), The Political Economy of Water Pricing Reforms. Oxford University Press.

Milliman, J. W. (1956). Commonality, the price system and the use of water supplies. Social Economic Journal 22: 426-437.

Milliman, J. W. (1959). Land values as measures of primary irrigation benefits. Journal of Farm Economics 41(2): 234-243.

Miranowski, J. A. and Hammes, D. B. (1984). Implicit prices of soil characteristics for farmland of Iowa. American Journal of Agricultural Economics 66(5): 645-649.

Mitchell, R. C. and Carson, R. T. (1989). Using Surveys to Value Public Goods: The Contingent Valuation Method. Baltimore, MD: John Hopkins University Press for Resources for the Future.

Montginoul, M. and Rieut, T. (1996). Instruments economiques et gestion de l'eau d'irrigation en France. La Houille Blanche 8: 47-54. 
Moore, M. and Negri, D. (1992). A multicrop production model of irrigated agriculture, applied to water allocation policy of the Bureau of Reclamation. Journal of Agricultural and Resource Economics 17: 29-43.

Moore, M., Gollehon, N. and Carey, M. (1994a). Multicrop production decisions in western irrigated agriculture: the role of water price. American Journal of Agricultural Economics 76: 859-874.

Moore, M., Gollehon, N. and Carey, M. (1994b). Alternative models of input allocation in multicrop systems: irrigation water in the central plains, United States. Agricultural Economics 11: 143-158.

Negri, D. H. (1989). The common property aquifer as a differential game. Water Resources Research 25: 9-15.

Negri, D. and Brooks, D. (1990). The determinants of irrigation technology choice. Western Journal of Agricultural Economics 15: 213-223.

Nieswiadomy, M. (1985). The demand for irrigation water in the High Plains of Texas, 1957-1980. American Journal of Agricultural Economics 67(3): 619-626.

Nieswiadomy, M. (1988). Input substitution in irrigated agriculture in the High Plains of Texas, 1970-80. Western Journal of Agricultural Economics 13: 63-70.

Noel, J. E., Gardner, B. D. and Moore, C. V. (1980). Optimal regional conjunctive water management. American Journal of Agricultural Economics 62: 489-498.

Oblitas, K., Raymond, J. P., in association with Gautam, P., Qaddumi, H. M. and Perera, J. (1999). Transferring irrigation management to farmers in Andhra Pradesh, India. Technical Paper no. 449. Washington, DC: World Bank.

Ogg, C. and Gollehon, N. (1989). Western irrigation response to pumping costs: a water demand analysis using climatic regions. Water Resources Research 25: 767-773.

Pearce, D., Groom, B., Hepburn, C. and Koundouri, P. (2003). Valuing the future: recent advances in social discounting. World Economics 4(2): 121-141.

Pearce, D. and Koundouri, P. (2003). Diffusion pollution and the role of agriculture. In D. Helm (ed.), Water Sustainability and Regulation: The Next Periodic Review and Beyond. OXERA Press.

Provencher, B. (1993). A private property rights regime to replenish a groundwater aquifer. Land Economics 69(4): 325-340.

Provencher, B. (1995). Issues in the conjunctive use of surface water and groundwater. In D. W. Bromley (ed.), The Handbook of Environmental Economics. Oxford, UK/ Cambridge, MA: Blackwell.

Provencher, B. and Burt, O. (1993). The externalities associated with the common property exploitation of groundwater. Journal of Environmental Economics and Management 24: 139-158.

Provencher, B. and Burt, O. (1994). A private property rights regime for the commons: the case for groundwater. American Journal of Agricultural Economics 875-888.

Rausser, G. C. (1992). Lessons for emerging market economies in eastern Europe. In C. Clague and G. C. Rausser (eds.), The Emergence of Market Economics in Eastern Europe. Cambridge, MA: Blackwell.

Rausser, G. C. (2000). Collective choice in water resource systems. In A. Dinar (ed.), The Political Economy of Water Pricing Reforms. Oxford University Press.

Rausser, G. C. and Simon, L. K. (1991). A non-cooperative model of collective design making: a multi-lateral bargaining approach. Working Paper no. 618. University of California, Department of Agricultural and Resource Economics Berkeley.

Renshaw, E. F. (1963). The management of ground water reservoirs. Journal of Farm Economics 45(2): 285-295.

Rosen, S. (1974). Hedonic prices and implicit markets: product differentiation in pure competition. Journal of Political Economy 2: 34-55.

Roseta-Palma, C. (2002). Groundwater management and endogenous water quality. Journal of Environmental Economics and Management 44: 93-105. 
Rubio, S. and Casino, B. (2003). Strategic behaviour and efficiency in the common property extraction of groundwater. Environmental and Resource Economics.

Schaible, G., Kim, C. and Whittlesey, N. (1991). Water conservation potential from irrigation technology transitions in the Pacific North-West. Western Journal of Agricultural Economics 16: 194-206.

Segerson, K. and Miceli, T. (1998). Voluntary environmental agreements: good or bad news for environmental protection? Journal of Environmental Economics and Management 36: 109-130.

Shah, F. A., Zilberman, D. and Chakravorty, U. (1995). Technology adoption in the presence of an exhaustible resource: the case of groundwater extraction. American Journal of Agricultural Economics 77(2): 291-299.

Shortle, J. and Abler, D. (1997). Non-point pollution. In H. Folmer and T. Tietenberg (eds.), International Yearbook of Environmental and Natural Resource Economics 1997-1998: A Survey of Current Issues, pp. 114-155. Cheltenham, UK: Edward-Elgar.

Shortle, J. and Horan, R. (2001). The economics of non-point pollution control. Journal of Economic Surveys 15(3): 255-289.

Shortle, J. and Laughland, A. (1994). Impacts of taxes to reduce agrochemical use when farm policy is endogenous. Journal of Agricultural Economics 45(1): 3-14.

Shunway, C. R. (1973). Derived demand for irrigation water: the California aqueduct. Southwestern Journal of Agricultural Economics 5: 195-200.

Shumway, C. R. and Chang, A. A. (1977). Linear programming versus positively estimated supply functions: an empirical and methodology critique. American Journal of Agricultural Economics 59: 344-357.

Smith, V. K. and Desvouges, W. H. (1986). Measuring Water Quality Benefits. Boston, MA: Kluwer Nijhoff.

Smith, R. B. W. and Tsur, Y. (1997). Asymmetric information and the pricing of natural resources: understanding the case of unmetered water. Land Economics 73(3): 392-403.

Stiglitz, J. (1974). Incentives and risk sharing in sharecropping. Review of Economic Studies 41: 219-255.

Tietenberg, T. (2002). Replenishable and Depletable Resources: Water. In Environmental and Natural Resource Economics, 6th edn. Addisson Wesley.

Toell, A., Libbin, J. and Miller, M. (1990). The market value of water in the Ogallala aquifer. Land Economics 66(2): 163-175.

Tsur, Y. (1990). The stabilization role of groundwater when surface water supplies are uncertain: the implications for groundwater development. Water Resources Research 26: 811-818.

Tsur, Y. (1991). Managing drainage problems in a conjunctive ground and surface water system. In A. Dinar and D. Zilberman (eds.), The Economics and Management of Water and Drainage in Agriculture. Dordrecht, The Netherlands: Kluwer.

Tsur, Y. (2000). Water regulation via pricing: the role of implementation costs and asymmetric information. In A. Dinar (ed.), The Political Economy of Water Pricing Reforms. Oxford University Press.

Tsur, Y. and Graham-Tomasi, T. (1991). The buffer value of groundwater with stochastic surface water supplies. Journal of Environmental Economics and Management 21: 201-224.

Tsur, Y. and Zemel, A. (1995). Uncertainty and irreversibility in groundwater resource management. Journal of Environmental Economics and Management 29: 149-161.

Tsur, Y. and Zemel, A. (1997). On event uncertainty and renewable resource management. In D. Parker and Y. Tsur (eds.), Decentralization and Cooperation of Water Resource Management. Dordrecht, The Netherlands: Kluwer.

Tsutsui, S. and Mino, K. (1990). Nonlinear strategies in dynamic duopolistic competition with sticky prices. Journal of Economic Theory 52: 136-161. 
Varela-Ortega, C., Sumpsi, J. M., Garrido, A., Blanco, M. and Iglesias, E. (1998). Water pricing policies, public decision making and farmers' response: implications for water policy. Agricultural Economics 19: 193-202.

Vickner, S., Hoag, D., Frasier, W. M. and Ascough, J. II (1998). A dynamic economic analysis of nitrate leaching in corn production under nonuniform irrigation conditions. American Journal of Agricultural Economics 80: 397-408.

Wagner, U. J. (2001). The design of stable international environmental agreements: economic theory and political economy. Journal of Economic Surveys 15(3): 377-411.

Wambia, J. M. (2000). The political economy of water resources institutional reform in Pakistan. In A. Dinar (ed.), The Political Economy of Water Pricing Reforms. Oxford University Press.

Williamson, J. (ed.) (1994). The Political Economy of Policy Reform. Washington, DC: Institute for International Economics.

Williamson, J. and Haggard, S. (1994). The political conditions for economic reform. In J. Williamson (ed.), The Political Economy of Policy Reform. Washington, DC: Institute for International Economics.

Wirl, F. (1994). The Ramsey model revisited: the optimality of cyclical consumption and growth. Journal of Economics 60: 81-98.

Worthington, V. E., Burt, O. R. and Brustkern, R. L. (1985). Optimal management of a confined aquifer system. Journal of Environmental Economics and Management 12: 229-245.

Xepapadeas, A. P. (1992). Environmental policy design and dynamic nonpoint-source pollution. Journal of Environmental Economics and Management 23: 22-39.

Xepapadeas, A. P. (ed.) (1996). Managing common-access resources under production externalities. In Economic Policy for the Environment and Natural Resources. Cheltenham, UK: Edward-Elgar.

Yadav, S. (1997). Dynamic optimization of nitrogen use when groundwater contamination is internalized at the standard in the long run. American Journal of Agricultural Economics 79: 931-945.

Young, R. A., Daubert, J. T. and Morel-Seytoux, J. (1986). Evaluating institutional alternatives for managing an interrelated stream-aquifer system. American Journal of Agricultural Economics November: 787-797.

Zeitouni, N. and Dinar, A. (1997). Mitigating negative water quantity and quality externalities by joint management of adjacent aquifers. Environmental and Resource Economics 9: 1-20.

Zilberman, D., Chakravorty, U. and Shah, F. (1997). Efficient management of water in agriculture. In D. D. Parker and Y. Tsur (eds.), Decentralization and Co-ordination of Water Resource Management, pp. 221-246. Dordrecht, The Netherlands: Kluwer.

Zilberman, D. and Lipper, L. (1999). The economics of water use. In: van den Bergh (ed.), Handbook of Environmental and Resource Economics. Cheltenham, UK: EdwardElgar.

Zilberman, D., MacDougall, N. and Shah, F. (1994). Changes in water allocation mechanisms for California agriculture. Contemporary Economic Policy 24(1): 1-17.

Zimmerman, W. R. (1990). Finite hydraulic conductivity effects on optimal groundwater pumping rates. Water Resources Research 26(12): 2861-2864. 


\section{Author Query Form}

\section{Journal: Journal of Economic Surveys}

\section{Article : kound.doc}

Dear Author,

During the copy-editing of your paper, the following queries arose. Please respond to these by marking up your proofs with the necessary changes/additions. Please write your answers on the query sheet if there is insufficient space on the page proofs. Please write clearly and follow the conventions shown on the attached corrections sheet. If returning the proof by fax do not write too close to the paper's edge. Please remember that illegible mark-ups may delay publication.

Many thanks for your assistance.

$\begin{array}{lll}\text { Query } & \text { Query } & \text { Remarks } \\ \text { Refs. } & & \end{array}$

$1 \quad \mathrm{Au}$ : Please check if the running head is OK.

2 Au: 'Sanchez' has been changed to 'Sánchez' to match that given in the reference list. Please check.

$3 \quad \mathrm{Au}$ : Please check if the equation numbers are $\mathrm{OK}$.

4

Au: Please clarify whether ' $p(w)$ ' should be ' $p(x)$ ', as given in the inline equation.

5 Au: 'Montginoul and Rieu, 1996' has been changed to

'Montginoul and Rieut, 1996' so that this citation matches that given in the reference list. Please check.

6 Au: 'Benardo et al. 1987' has been changed to 'Bernardo et al. 1987 ' so that this citation matches that given in the reference list. Please check.

$7 \quad$ Au: 'Howit et al., 1980' has been changed to 'Howitt et al., 1980' so that this citation matches that given in the reference list. Please check.

8 Au: 'Montginoul and Rieu, 1996' has been changed to 'Montginoul and Rieut, 1996' so that this citation matches that given in the reference list. Please check.

Au: 'Koundouri et al. 2003' has been change to 'Koundouri et al. $2003 \mathrm{a}, \mathrm{b}$ ' to match the change made in the reference list. Please check. 
Query Query

Refs.

10 Au: 'Hartman \& Anderson 1963' has been changed to 'Hartman \& Anderson 1962' so that this citation matches that given in the reference list. Please check.

11 Au: There is no section '2.6.2' in this article. Please check.

12 Au: Please clarify whether 'Harsanyi' should be 'Hrsanyi' as in the previous paragraph.

13 Au: Please clarify whether the following text is OK: 'negotiate a comprise agreement'.

14 Au: 'Bromely 2000' has been changed to 'Bromley 2000' so that this citation matches that given in the reference list. Please check.

15 Au: 'Bromely 2000' has been changed to 'Bromley 2000' so that this citation matches that given in the reference list. Please check.

16 Au: 'McCann and Zilberman, 2000' has been changed to 'McCann and Zilbermand, 2000' so that this citation matches that given in the reference list. Please check.

17 Au: 'Israel 1987' has not been included in the reference list. Please check.

18 Au: 'Haggard \& Webb 1996b' has been changed to 'Haggard \& Webb 1996' so that this citation matches that given in the reference list. Please check.

19 Au: Please provide the volume number.

20 Au: 'de Azevedo \& Asad 2000' has not been cited in the text. Also, Please provide the city and country of the publisher.

21 Au: Please provide the city and country of the publisher.

22 Au: Please provide the city and country of the publisher.

23 Au: Please provide the city and country of the publisher.

24 Au: Please provide the city and country of the publisher.

$\mathrm{Au}$ : Please provide the city and country of the publisher. 
Refs.

26 Au: Please provide the volume number and page range to complete this reference.

$27 \quad \mathrm{Au}$ : Please provide the volume number.

28 Au: 'Gisser 1983' has not been cited in the text. Please check.

29 Au: Please provide the city and country of the publisher.

30 Au: Please provide the city of the publisher.

31 Au: Please clarify whether the state of the publisher is OK.

$32 \mathrm{Au}$ : Please provide the city and country of the publisher.

33 Au: Please provide the volume number.

34 Au: Please provide the city and country of 'University of Cambridge'.

35 Au: Please provide the city and country of the publisher.

36 Au: Please provide the country of 'Rethymnon'.

37 Au: Please provide the volume number and the page range to complete this reference.

38 Au: Please provide the city, state and country name of the publisher.

39 Au: '2003' has been changed to '2003a'. Please check.

40 Au: Please provide the city and country of the publisher. Also, '2003' has been changed to '2003b'. Please check.

41 Au: Please provide the city and state of 'Iowa State University'.

42 Au: 'Love \& Buccola 1999' has not been cited in the text. Please check. 


\begin{tabular}{lll}
\hline Query & Query & Remarks \\
Refs. &
\end{tabular}

Refs.

$44 \quad \mathrm{Au}$ : Please provide the city and country of the publisher.

$45 \quad$ Au: Please provide the volume number.

46 Au: 'Rausser 1992' has not been cited in the text. Please check.

$47 \quad \mathrm{Au}$ : Please provide the city and country of the publisher.

48 Au: Please provide the city and state of 'University of California'.

49 Au: Please provide the volume number and the page range to complete this reference.

$50 \quad \mathrm{Au}$ : Please provide the city and country of the publisher.

51 Au: 'aater' has been changed to 'water'. Please clarify whether this is $\mathrm{OK}$.

52 Au: Please provide the city and country of the publisher.

53 Au: Please provide the city and country of the publisher.

$54 \quad$ Au: 'Young et al. 1986' has not been cited in the text. Please check.

55 Au: Please provide the initial(s) of 'van den Bergh'. 